Published in final edited form as:

Heart Rhythm. 2015 August ; 12(8): 1852-1866. doi:10.1016/j.hrthm.2015.04.014.

\title{
J Wave syndromes: Brugada and Early Repolarization Syndromes
}

Charles Antzelevitch, PhD, FHRS ${ }^{1}$ and Gan-Xin Yan, MD, PhD $2,3,4$

1 SUNY Upstate Medical University, Syracuse, NY, USA.

${ }^{2}$ Lankenau Institute for Medical Research and Lankenau Medical Center, Wynnewood, PA, USA.

3 Jefferson Medical College, Philadelphia, PA, USA.

${ }^{4}$ The First Affiliated Hospital, Medical School of Xi'an Jiaotong University, Xi'an, China

\begin{abstract}
A prominent $\mathbf{J}$ wave is encountered in a number of life-threatening cardiac arrhythmia syndromes, including the Brugada (BrS) and early repolarization (ERS) syndromes. BrS and ERS differ with respect to the magnitude and lead location of abnormal $\mathrm{J}$ waves and are thought to represent a continuous spectrum of phenotypic expression termed J wave syndromes. Despite two decades of intensive research, risk stratification and the approach to therapy of these two inherited cardiac arrhythmia syndromes are still undergoing rapid evolution. Our objective in this review is to provide an integrated synopsis of the clinical characteristics, risk stratifiers, as well as the molecular, ionic, cellular and genetic mechanisms underlying these two fascinating syndromes that have captured the interest and attention of the cardiology community in recent years.
\end{abstract}

\section{Keywords}

Sudden cardiac death; J wave; Early repolarization; ST segment elevation; Cardiac arrhythmias; ventricular tachycardia; ventricular fibrillation; inherited cardiac arrhythmias syndromes

\section{Introduction}

A prominent $\mathrm{J}$ wave in humans has long been observed in the ECG in cases of hypothermia ${ }^{1-3}$ and hypercalcemia. ${ }^{4,5}$ More recently, the presence of prominent $\mathbf{J}$ waves has been identified as a marker for a substrate capable of generating life-threatening ventricular arrhythmias. ${ }^{6}$ In humans, the $\mathrm{J}$ wave more commonly appears as a J point elevation, with part of the J wave buried inside the QRS. When greatly amplified, it can appear as an ST segment elevation, as in cases of Brugada syndrome.

An early repolarization (ER) pattern in the electrocardiogram (ECG), consisting of a distinct J wave or J point elevation, a notch or slur of the terminal part of the QRS and an ST

Address for correspondence: Dr. Charles Antzelevitch Department of Pharmacology SUNY Upstate Medical University Syracuse, NY 13210 cantzelevitch@gmail.com.

Disclosures: Dr. Antzelevitch is a consultant for Gilead Sciences and received funding from Gilead Sciences and Buchang Pharmaceuticals. 
segment elevation (Figure 1), is generally found in healthy young males and has traditionally been viewed as benign. 7,8 This view was challenged by us in the late 1990s and early 2000s on the basis of experimental data showing that an ER pattern in the canine coronary-perfused wedge preparation predisposes to the development of polymorphic ventricular tachycardia and fibrillation (VT/VF). ${ }^{6,9-11}$ Validation of this hypothesis was provided eight years later by Haïssaguerre et al. ${ }^{12}$ and Nam et al. ${ }^{13}$ These reports together with numerous additional case control and population-based studies provided clinical evidence of an increased prevalence of ER pattern, particularly in inferior and infero-lateral leads, among patients with a history of idiopathic ventricular fibrillation, thus confirming a link between ER pattern in the ECG and life-threatening cardiac arrhythmias. Terminology relative to ER has been a matter of confusion and contention. ${ }^{14-16}$ A recent expert consensus report recommends that peak of an end QRS notch and/or the onset of an end QRS slur be designated as $\mathrm{J}(\mathrm{p})$ and that $\mathrm{J}(\mathrm{p})$ should exceed $0.1 \mathrm{mV}$ in $\geq 2$ contiguous inferior and/or lateral leads of a standard 12-lead ECG for early repolarization to be present. ${ }^{17}$

\section{The two principal forms of $\mathbf{J}$ wave syndrome}

Two distinct forms of inherited $\mathrm{J}$ wave syndromes are recognized: Early repolarization syndrome (ERS) and Brugada syndrome (BrS). Both are associated with vulnerability to polymorphic ventricular tachycardia (VT) and ventricular fibrillation (VF) leading to sudden cardiac death $^{6}, 12,13,18$ in young adults without apparent structural heart disease. $\mathbf{J}$ wave syndromes are characterized by J-point and ST-elevation in distinct ECG-leads. The J wave syndromes have also, although far less often, been associated with sudden infant death syndrome (SIDS). ${ }^{19-21} \mathrm{BrS}$ is the right ventricular variant of hereditary $\mathbf{J}$ wave syndromes. The region most affected by the disease is the anterior right ventricular outflow tract. BrS patients display J-point and ST-segment elevation in the right precordial leads. ${ }^{22,} 23$

An early repolarization ECG-pattern (ERP) is characterized by a distinct $\mathbf{J}$ wave or J-pointelevation, notch or slur of the terminal part of the QRS and ST-elevation in the lateral (type I), infero-lateral (type II) or in infero-lateral + anterior or right ventricular leads (type III). ERP can be observed in acquired conditions such as hypothermia or ischemia. $6,24,25$ When associated with VT/VF, it is referred to as early repolarization syndrome (ERS). Despite the different regional localization within the heart, BrS and ERS display several clinical similarities, suggesting similar pathophysiology (Table 1). ${ }^{10,14,26-28}$ Previous studies have pointed to different pathophysiological basis based on the observation that sodium channel blockers unmask or accentuate $\mathrm{J}$ wave manifestation in $\mathrm{BrS}$, but reduces the amplitude in ERS. ${ }^{29}$ The recent study by Nakagawa et al., however, showed that J waves recorded using unipolar LV epicardial leads introduced into the left lateral coronary vein in ERS patients were indeed augmented, even though $\mathbf{J}$ waves recorded in the lateral precordial leads were diminished, due principally to engulfment of the surface $\mathrm{J}$ wave by the widened QRS. ${ }^{30}$ Interestingly, the study of Kawata et al. showing an effect of pilsicainide to augment $\mathrm{J}$ waves and ST segment elevation in the right precordial leads, while reducing ER in the lateral leads in the same patient, actually provides support for a similar mechanism of ERS and BrS in light of the results advanced by Nakagawa and co-workers. ${ }^{29}$ Also in support of the notion that these ECG patterns and syndromes are closely related are reports of cases of ERS that at times transition to ERS plus BrS. ${ }^{31,} 32$ 
ERS and BrS share a number of common clinical features (Table 1): Males are dominant in both syndromes: in the Brugada syndrome, the percentage of males involved ranges from 71 to $80 \%$ in Caucasians but as high as $94 \%-96 \%$ in Japanese. ${ }^{33,34}$ Similarly, in the setting of ER pattern, males develop ventricular fibrillation in $60 \%$ of cases in the study of Haïssaguerre et al ${ }^{12}$ but in a much higher percentage reported by Japanese investigators. ${ }^{29}$ The patients with BrS or ERS may be totally asymptomatic until presenting with syncope and sudden cardiac arrest often due to ventricular fibrillation. The risk for development of VT/VF is dictated in large part by the ER subtype (Type I, II or III), as previously discussed. ${ }^{6}$ In both syndromes, the highest incidence of ventricular fibrillation or sudden cardiac death occurs in the third decade of life when testosterone levels peak in males. ${ }^{35}$ Another important clinical feature of both syndromes is that $\mathrm{J}$ wave and associated ST segment elevation are accentuated during bradycardia or after pauses. ${ }^{36,37}$ This may explain why ventricular fibrillation in both syndromes often occurs during sleep or at a low level of physical activities. ${ }^{29,38}$

In addition to reports of SCD in otherwise healthy patients displaying an ER pattern, this ECG pattern has been associated with an increased arrhythmogenic risk and SCD in patients with acute myocardial infarction ${ }^{39}$, chronic coronary disease ${ }^{40}$, heart failure ${ }^{41}$ and hypothermia 24,42

\section{Genetics}

$\mathrm{BrS}$ has been associated with mutations in 19 different genes (Table 2). To date more than 300 BrS-related mutations in SCN5A have been described ${ }^{14,43,44}$ Mutations in CACNAIC (Cav1.2), CACNB2b (Cavß2b) and CACNA2D1 (Cava28) are found in approximately 13\% of probands. ${ }^{45-48}$ Mutations in glycerol-3-phophate dehydrogenase 1-like enzyme gene (GPDIL), SCN1B ( $\beta_{1}$-subunit of Na channel), KCNE3 (MiRP2), SCN3B ( $\beta 3$-subunit of Na channel), KCNJ8 (Kir 6.1), KCND3 (Kv4.3), RANGRF (MOG1), SLMAP, ABCC9 (SUR2A), (Navß2), PKP2 (Plakophillin-2), FGF12 (FHAF1), HEY2, and SEMA3A (Semaphorin) are more rare. ${ }^{49-5354-6153,62-69}$ We recently reported an association of BrS with $S C N 10 A$, a neuronal sodium channel that co-associates with $S C N 5 A$, with a yield of $16.7 \% .^{70}$ Mutations in these genes lead to loss of function in sodium channel current $\left(\mathrm{I}_{\mathrm{Na}}\right)$ and calcium channel current $\left(\mathrm{I}_{\mathrm{Ca}}\right)$, as well as to a gain of function in transient outward potassium current $\left(\mathrm{I}_{\mathrm{to}}\right.$ ) or ATP-sensitive potassium current ( $\mathrm{I}_{\mathrm{K}-\mathrm{ATP}}$ ). Mutations in $\mathrm{KCNH} 2$ and $K C N E 5$, although not causative, have been identified as capable of modulating the substrate for the development of BrS. Loss-of-function mutations in HCN4 causing a reduction in pacemaker current, $\mathrm{I}_{\mathrm{f}}$, can unmask $\mathrm{BrS}$ by reducing heart rate. ${ }^{71}$

The familial nature of the ER pattern has been demonstrated in a number of studies. ${ }^{72-74}$ The ER pattern and ERS have been associated with mutations in 7 genes. Consistent with the findings that $\mathrm{I}_{\mathrm{K}-\mathrm{ATP}}$ activation can generate an ER pattern in canine ventricular wedge preparations, mutations in $K C N J 8$ and $A B C C 9$, responsible for the pore forming and ATPsensing subunits of the $\mathrm{I}_{\mathrm{K}-\mathrm{ATP}}$ channel, has been reported in a patients with ERS as well. ${ }^{49,51,75}$ Loss of function mutations in the $\alpha 1, \alpha 2$ and $a 2 \delta$ subunits of the cardiac Ltype calcium channel (CACNA1C, CACNB2, and CACNA2D1) have been uncovered in 
patients with ERS ${ }^{45}$ as have mutations in $S C N 5 A .^{76}$ We have also recently reported an association of SCN1OA with ERS. ${ }^{70}$

A word of caution is appropriate here. It is important to recognize that a small fraction of identified genetic variants in the numerous genes associated with $\mathrm{BrS}$ and ERS have been examined using functional expression studies to establish causality or to establish a plausible contribution to pathogenesis. Only a handful have been studied in genetically engineered animal model and very few have been studied in native cardiac cells or in induced pluripotent stem cell-derived cardiac myocytes isolated from ERS and BrS patients. Computational strategies developed to predict the functional consequences of mutations are helpful, but these methods have not been rigorously tested. The lack of functional or biological validation of mutation effects remains the most severe limitation of genetic test interpretation as recently highlighted by Schwartz et al. ${ }^{77}$ This limitation is still more concerning in cases in which a susceptibility gene is identified on the basis of a single proband and with the absence of familial segregation data. Recent studies have suggested a more complex genetic background for $\mathrm{BrS}$. Bezzina et $\mathrm{al}^{60}$ provided evidence that $\mathrm{BrS}$ is associated with common genetic variants suggesting a multigenic origin of the syndrome. Other authors, including Le Scouarnec et al ${ }^{78}$ and Behr et al ${ }^{79}$, have questioned the impact of rare gene-variants, with the exception of SCN5A, in the pathogenesis of the synmdrome. These studies once again call for caution in the interpretation of genetic resutls as well as the need for genotype-phenotype correlation data and functional expression data before designating a rare variants as causative of the disease.

\section{Ionic and Cellular Mechanisms}

The $\mathbf{J}$ wave is inscribed as a consequence of a transmural voltage gradient caused by the presence of an action potential notch in epicardium but not endocardium, secondary to a transmural distribution of transient outward current $\left(\mathrm{I}_{\mathrm{to}}\right) \cdot{ }^{27}$

The cellular mechanisms underlying $\mathbf{J}$ wave syndromes have been mired in controversy. ${ }^{80,81}$ Two principal hypotheses have been advanced in the case of $\mathrm{BrS}$ (Figure 2): 1) The repolarization hypothesis maintains that an outward shift in the balance of currents in right ventricular epicardium leads to repolarization abnormalities resulting in the development of phase 2 reentry, which generates closely-coupled premature beats capable of precipitating VT/VF; 2) The depolarization hypothesis maintains that slow conduction in the right ventricular outflow tract plays a primary role in the development of the electrocardiographic and arrhythmic manifestations of the syndrome. Although these theories are not mutually exclusive and may indeed be synergistic, from the standpoint of appropriate therapy, correct assessment of the cellular pathophysiology is important.

The most compelling evidence in support of the depolarization hypothesis comes from a study by Nademanee et al. ${ }^{82}$ showing that radiofrequency (RF) ablation of epicardial sites displaying late potentials and fractionated bipolar electrograms (EGs) in the right ventricular outflow tract (RVOT) of BrS patients significantly reduced the arrhythmia-vulnerability and ECG-manifestation of the disease. These authors concluded that the late potential (LP) and fractionated electrogram activity are due to conduction delays within the RVOT and elimination of the sites of slow conduction is the basis for the ameliorative effect of ablation 
therapy. ${ }^{82}$ In a direct test of this hypothesis, our group recently suggested an alternative cellular electrophysiological mechanism as the basis for late potentials and fractionated electrogram activity in the setting of BrS. ${ }^{83}$ As illustrated in Figure 3, when the genetic defects associated with $\mathrm{BrS}$ are pharmacologically mimicked in the coronary-perfused canine right ventricular wedge model of $\mathrm{BrS}$, high frequency late potentials develop in the right ventricular (RV) epicardium secondary to concealed phase 2 reentry. At other sites, low-voltage fractionated electrogram activity develops due to regional desynchronization in the appearance of the second action potential upstroke, secondary to accentuation of the epicardial action potential notch. In no case was delayed conduction of the primary beat observed.

If late potentials and fractionated electrogram activity recorded from the RVOT do not reflect depolarization and conduction abnormalities, what is the basis for the ameliorative effect of RVOT ablation? Figure 4 illustrates that ablation of sites of phase 2 reentry in the canine ventricular wedge model of BrS markedly diminishes the manifestation of $\mathbf{J}$ waves and ST segment elevation and abolishes all arrhythmic activity. The data provide support for the hypothesis that ablation destroys the cells with the most prominent action potential notch, thus eliminating the cells responsible for the repolarization abnormalities that give rise to phase 2 reentry and VT/VF. These findings collectively lend strong support for the repolarization hypothesis. Also in support of this thesis is the congruence between $\mathrm{BrS}$ and ERS, which by virtue of its name is considered to be due to a repolarization defect.

Conduction delays are known to give rise to notching of the QRS complex. Although such notching often occurs on the rising phase of the QRS or during the middle of the descending phase, it can occur at the terminal portion of the QRS, thus masquerading as a J wave. ${ }^{14,} 84$ How then can we differentiate an end of QRS notch from a J wave? One method that we and others have previously suggested is to gauge the response to prematurity or to an increase in rate. Delayed conduction invariably becomes worse at faster rates or during premature beats thus leading to an accentuation of the notch, whereas repolarization defects are usually mitigated resulting in a diminution of the $\mathbf{J}$ wave at faster rates. Although typical $\mathbf{J}$ waves are usually accentuated with bradycardia or long pauses, the opposite has been described. ${ }^{85}, 86 \mathrm{~J}$ waves are often seen in young males with no apparent structural heart diseases, whereas intra-ventricular conduction delay is often observed in older individuals or those with a history of myocardial infarction or cardiomyopathy. Figure 5 illustrates examples of both.

The tachycardia-augmented notches (Figure 5D) can result in apparent "J" waves that are as tall or taller than $50 \%$ of the $\mathrm{R}$ wave $\mathrm{e}^{85}$ and as such may be more reasonably characterized as an R' due to intra-ventricular conduction delay. ${ }^{84}$ The prognostic value of a fragmented QRS has been demonstrated in $\mathrm{BrS},{ }^{87,88}$ although fragmentation of the QRS is not associated with increased risk in the absence of cardiac disease. ${ }^{89}$ Factors that may aid in the differential diagnosis of J wave vs IVCD-mediated syndromes are summarized in Table 4.

The ionic and cellular mechanisms underlying ERS were recently advanced in a report by Koncz and co-workers. ${ }^{90}$ The authors provided evidence in support of the hypothesis that, similar to the mechanism operative in BrS, an accentuation of transmural gradients, in this case across the LV wall, underlies the repolarization abnormalities responsible for ERS, 
giving rise to J point elevation, distinct J waves, or slurring of the terminal part of the QRS

(Figure 1). The repolarization defect is accentuated by cholinergic agonists and reduced by quinidine, isoproterenol, cilostazol and milrinone, accounting for the ability of these agents to reverse the repolarization abnormalities responsible for ERS. ${ }^{90,91}$ These authors also showed significantly higher intrinsic levels of $\mathrm{I}_{\text {to }}$ in the inferior $\mathrm{LV}$, providing an explanation for the greater vulnerability of the inferior LV wall to VT/VF. ${ }^{90}$ The clinical translation of these experimental findings has been facilitated by the advent and implementation of electrocardiographic imaging (ECGI) by Rudy and co-workers. Using ECGI mapping, Ghosh et al. identified abnormally short activation-recovery intervals (ARI) in the inferior and lateral regions of LV and a marked dispersion of repolarization in support of regional accelerated repolarization. ${ }^{92}$ More recent studies involving ECGI mapping in an ERS patient during VF have demonstrated VF rotors anchored in the inferior-lateral left ventricular wall. ${ }^{15}$

\section{Risk stratification}

A great deal of effort has been devoted to assessment of risk for the development of lifethreatening arrhythmias. The incidental discovery of a $\mathbf{J}$ wave on routine screening should not be interpreted as a marker of "high risk" for SCD since the odds for this fatal disease is approximately $1: 10,000 .^{93}$ Rosso et al. indicated that the presence of a J wave on the ECG increases the probability of VF from 3.4:100,000 to 11:100,000. ${ }^{94,}{ }^{95}$ However, careful attention should be paid to subjects with "high risk" ER or J waves. Table 3 presents the available data of studies designed to identify patients at high risk. Among these risk stratifiers, some are highly predictive, including: 1 ) history of cardiac events or syncope likely due to VT/VF, 2) pause-dependent augmentation of $\mathbf{J}$ waves, especially when accompanied by $\mathrm{T}$ wave inversion, and 3 ) prominent $\mathbf{J}$ waves in global leads including Type $1 \mathrm{ST}$ segment elevation in the right precordial leads. Fragmentation of the QRS, although predictive of cardiac events in the $\mathrm{J}$ wave syndromes, is non-specific in that it is associated with a high risk of sudden death in other cardiac arrhythmia syndromes.

In the case of ERS, the morphology of the ST segment is reported to be associated with increased arrhythmic risk. Tikkanen et al were the first to suggest that a horizontal or descending ST segments portends a higher risk for arrhythmic events and SCD. ${ }^{96} \mathrm{In}$ contrast, an ER pattern with a rapidly ascending pattern, typically observed in healthy athletes, was associated with a relatively benign prognosis. Rosso et al. and Rollin et al. reported additional evidence linking a horizontal ST segment to an increased risk for SCD soon thereafter. ${ }^{97,} 98$

In a recent review, Mahida and coworkers concluded that the presence of inferior or widespread J point elevation, a markedly elevated J point, a horizontal or descending ST segment, pause-dependent augmentation of the J wave amplitude, short coupled extrasystoles, and QRS notching predict progressively greater risk for SCD in patients presenting with syncope. ${ }^{15}$ 


\section{Approaches to therapy}

Implantation of an ICD is the mainstay of therapy for $\mathbf{J}$ wave syndrome patients presenting with aborted SCD or documented VT/VF with or without syncope (Class I recommendation). ${ }^{99,100}$ According to the 2013 HRS/EHRA/APHRS consensus statement, ICDs can be useful (Class IIa) in symptomatic BrS patients with Type I pattern, in whom syncope was likely caused by VT/VF and may be considered (Class IIb) in asymptomatic patients inducible by programmed electrical stimulation (PES).${ }^{101}$ ICDs are not indicated in asymptomatic patients. There is no clear role for PES in patients with ERS.

Pacemaker therapy-Although arrhythmias and sudden cardiac death generally occur during sleep or at rest and have been associated with slow heart rates, a potential therapeutic role for cardiac pacing remains largely unexplored. ${ }^{102}$

Only a few case reports are available in the literature. ${ }^{103,104}$

Radiofrequency Ablation Therapy-Nademanee et al. ${ }^{82}$ showed that radiofrequency (RF) ablation of epicardial sites displaying late potentials and fractionated bipolar electrograms (EGs) in the right ventricular outflow tract (RVOT) of BrS patients can significantly reduce arrhythmia-vulnerability and the ECG-manifestation of the disease. Ablation at these sites was reported to render VT/VF non-inducible and to normalize the Brugada ECG pattern in the majority of patients over a period of weeks or months. Longterm follow-up ( $20 \pm 6$ months) showed no recurrent VT/VF with only 1 patient on medical therapy with amiodarone. Since then, case reports have been published in support of these effects. ${ }^{105}$ Ablation therapy can be life-saving in otherwise uncontrollable cases or cases in which ICD therapy is contraindicated. In the HRS/EHRA/APHRS expert consensus guideline, radiofrequency ablation is a Class IIb recommendation in BrS-patient with frequent appropriate ICD-shocks due to recurrent electrical storms. ${ }^{101}$ There are no clinical reports of ablation of the LV substrate in patients with ERS.

\section{Pharmacologic approach to therapy}

Approach to therapy of BrS-ICD implantation may not be a practical solution for infants and young children due to a high complication rate or for patients residing in regions of the world where an ICD is out of reach because of economic factors. A pharmacologic approach to therapy, based on a rebalancing of currents active during the early phases of the epicardial action potential in the right ventricle so as to reduce the magnitude of the action potential notch and/or restore the action potential dome, has been a focus of basic and clinical research in recent years. Table 5 lists the various pharmacologic agents thus far investigated. Antiarrhythmic agents such as amiodarone and $\beta$ blockers have been shown to be ineffective. ${ }^{106}$ Class IC antiarrhythmic drugs (such as flecainide and propafenone) and class IA agents, such as procainamide, are contraindicated because of their effects to unmask the Brugada syndrome and induce arrhythmogenesis. Disopyramide is a class IA antiarrhythmic that has been demonstrated to normalize ST segment elevation in some Brugada patients but to unmask the syndrome in others. ${ }^{107}$ 
Because the presence of a prominent transient outward current, $\mathrm{I}_{\mathrm{to}}$, is central to the mechanism underlying $\mathrm{BrS}$ and ERS, the most rationale approach to therapy, regardless of the ionic or genetic basis for the disease, is to partially inhibit $\mathrm{I}_{\mathrm{to}}$. Cardio-selective and $\mathrm{I}_{\mathrm{to}^{-}}$ specific blockers are not currently available. 4-aminopyridine (4-AP) is an agent that is ionchannel specific at low concentrations, but is not cardio-selective in that it inhibits $I_{\text {to }}$ in the nervous system. Although it is effective in suppressing arrhythmogenesis in wedge models of the Brugada syndrome, ${ }^{10}$ it is unlikely to be of clinical benefit because of neurallymediated and other side effects.

The only agent on the market in the United States and around the world with significant $\mathrm{I}_{\text {to }}$ blocking properties is quinidine. It is for this reason that we suggested in 1999 that this agent may be of therapeutic value in BrS. ${ }^{10,108}$ Experimental studies have since shown quinidine to be effective in restoring the epicardial action potential dome, thus normalizing the ST segment and preventing phase 2 reentry and polymorphic VT in different experimental models of the Brugada syndrome, regardless of which pharmacologic agents were used to mimic BrS-phenotype. 10, 83, 109-111 Additionally, a recent experimental study suggests that quinidine, owing to its effect to block $\mathrm{I}_{\text {to }}$, can exert a protective effect against hypothermiainduced VT/VF in a $\mathbf{J}$ wave syndrome model. ${ }^{42}$ It is noteworthy that historically, quinidine was used to prevent ventricular fibrillation in patients who required hypothermia for surgical procedures. 111

Clinical evidence of the effectiveness of quinidine in normalizing ST segment elevation and or preventing arrhythmic events in patients with the BrS has been reported in numerous studies and case reports ${ }^{112-126}$ The first prospective study describing the effects of quinidine to prevent inducible and spontaneous ventricular fibrillation (VF) was reported by Belhassen and coworkers. ${ }^{115}$ The results were consistent with those reported the same group in prior years 113,127 and later by other investigators 128,129 . The data highlight the need for randomized clinical trials to assess the effectiveness of quinidine, preferably in patients with frequent events who have already received an ICD. Hermida et al. reported $76 \%$ efficacy in prevention of VF induced by PES. ${ }^{128}$

Because of the GI side effects of high dose quinidine, low-dose quinidine $(<600 \mathrm{mg})$ has been suggested to be as a therapeutic option. Marquez et al. evaluated the clinical history of symptomatic patients with recurrent arrhythmias and frequent ICD discharges and reported that relatively low dose quinidine, as adjunctive therapy, completely prevented arrhythmias in $85 \%$ of the patients (median follow-up of 4years). ${ }^{118}$.

In a more recent trial conducted at two French centers, 44 asymptomatic BrS patients with inducible VT/VF were enrolled ( $47 \pm 10$ years, $95 \%$ male). ${ }^{130}$ Of these, $34(77 \%)$ were no longer inducible while treated with $600 \mathrm{mg}$ /day hydroquinidine (HQ) for $6.2 \pm 3$ years.

Among the 10 other patients (22\%), who remained inducible and received ICD (Group PVS + ), none received appropriate therapy during a mean follow-up of $7.7 \pm 2$ years. The overall annual rate of arrhythmic events was $1.04 \%$, without significant difference between inducibility under HQ. One-third of patients experienced device-related complications. 
A prospective registry of empiric quinidine for asymptomatic Brugada syndrome has been established. The study appears at the National Institutes of Health website (ClinicalTrials.gov) and can be accessed at http://clinicaltrials.gov/ct2/show/NCT00789165? term_brugada\&rank_2. Doses between 600 and $900 \mathrm{mg}$ were recommended, if tolerated. ${ }^{116}$

In the latest_HRS/EHRA/APHRS expert consensus statement, quinidine was given a class IIa recommendation in BrS patients who are qualified for an ICD but in whom hindering factors are present, IIa in ICD-patients with electrical storms, and IIb recommendation in asymptomatic BrS-patients displaying a spontaneous Type I ECG. ${ }^{101}$

The development of a more cardio-selective and $\mathrm{I}_{\mathrm{to}}$-specific blocker would be a most welcome addition to the limited therapeutic armamentarium currently available to combat this disease. Agents that augment the L-type calcium channel current, such as $\beta$ adrenergic agents like isoproterenol, denopamine or orciprenaline, are useful as well. $10,121,125,131-133$ Isoproterenol, sometimes in combination with quinidine, has been utilized successfully to control VF storms and normalizing ST elevation particularly in children 113,114, 125, 129, 134-141. 119, 142-146. The occurrence of spontaneous VF in patients with Brugada syndrome is often related to increases in vagal tone and correspondingly electrical storm is sometimes treatable by the increase of sympathetic tone via isoproterenol administration. In the latest HRS/EHRA/APHRS guideline, Isoprotereonol has a Class IIa recommendation for $\mathrm{BrS}$ patients presenting with electrical storms. ${ }^{101}$

Another promising pharmacologic approach is the administration of phosphodiesterase III inhibitor cilostazol $125,132,147$, which normalizes the ST segment, most likely by augmenting calcium current $\left(\mathrm{I}_{\mathrm{Ca}}\right)$ as well as by reducing $\mathrm{I}_{\text {to }}$ secondary to an increase in cAMP and heart rate. ${ }^{148}$ Other diverse effects of cilostazol in playing a role in its beneficial impact cannot be excluded. (e.g.: adenosine, $\mathrm{NO}$, mitochondrial $\mathrm{I}_{\mathrm{KATP}}{ }^{149}$ ) Its efficacy in combination with bepridil in preventing VF-episodes was recently reported by Shinoharaet al. ${ }^{150} \mathrm{~A}$ case report describing the failure of cilostazol in the treatment of a BrS-patient is also available in the literature. ${ }^{151}$

Milrinone is another phosphodiesterase III inhibitor recently identified as a more potent alternative to cilostazol in suppressing ST elevation and arrhythmogenesis in an experimental model of $\mathrm{BrS} .^{83,152}$ No clinical reports have appeared as yet.

Wenxin Keli, a traditional Chinese medicine (TCM), in addition to its actions to suppress atrial fibrillation by atrial-selective inhibition of $\mathrm{I}_{\mathrm{Na}}$-dependent parameters ${ }^{153}$, has recently been shown to inhibit $\mathrm{I}_{\text {to }}$ and thus to suppress polymorphic VT in experimental models of $\mathrm{BrS}$ when combined with low concentrations of quinidine $(5 \mu \mathrm{M}) .{ }^{110} \mathrm{~A}$ recent study has also reported the effect of Wenxin Keli to suppress ischemia-induced ventricular arrhythmias. ${ }^{154}$

Agents that augment sodium channel current active during the early phases of the action potential, including bepridil and dimethyl lithospermate B (dmLSB), have been suggested to be of value in BrS. Bepridil has been reported to suppress VT/VF in several studies of patients with BrS. ${ }^{125,155-157}$ The drug's action are thought to be mediated by: 1) inhibition of $\mathrm{I}_{\mathrm{to}}$; 2) augmentation of $\mathrm{I}_{\mathrm{Na}}$ via upregulation of the channels ${ }^{158}$; and 3) prolongation of QT 
interval at slow rates thus increasing the QT/RR slope. ${ }^{155,157}$ Dimethyl lithospermate B, an extract of Danshen, a traditional Chinese herbal remedy, has been reported to slow inactivation of $\mathrm{I}_{\mathrm{Na}}$ thus increasing $\mathrm{I}_{\mathrm{Na}}$ during the early phases of the action potential (AP) and thus to suppress arrhythmogenesis in experimental models of $\mathrm{BrS} .{ }^{159}$

Approach to therapy of ERS-It is not surprising that the approach to therapy of ERS is similar to that of $\mathrm{BrS}$, since the mechanisms underlying the two syndromes are similar. Quinidine, phosphodiesterase III inhibitors and isoproterenol have all been shown to exert an ameliorative effect in preventing or quieting arrhythmias associated with ERS.

Isoproterenol has been shown to be effective in quieting electrical storms developing in patients with either $\mathrm{BrS}^{125,134}$ or $\mathrm{ERS}^{75}$. Isoproterenol acts by increasing $\mathrm{I}_{\mathrm{Ca}}$, thus leading to a reversal of repolarization abnormalities secondary to restoration of the epicardial action potential dome in experimental models of BrS 10,109 and ERS 90 .

The phosphodiesterase (PDE) III inhibitor cilostazol has been reported to reduce the ECG and arrhythmic manifestations of ERS. ${ }^{160}$ PDE inhibitors are known to activate $\mathrm{I}_{\mathrm{Ca}}$ secondary to an increase in cAMP. ${ }^{132,148,161-165}$ The augmentation of $\mathrm{I}_{\mathrm{Ca}}$ is thought to prevent arrhythmias associated with the $\mathrm{J}$ wave syndromes by reversing the repolarization defects and restoring electrical homogeneity across the ventricular wall secondary to restoration of the epicardial action potential dome in both $\mathrm{BrS}^{152}$ and ERS. ${ }^{42}$ Cilostazol has been hypothesized to also block $\mathrm{I}_{\text {to }}$. Augmentation of $\mathrm{I}_{\mathrm{Ca}}$ together with inhibition of $\mathrm{I}_{\mathrm{to}}$ are expected to produce an inward shift in the balance of currents active during the early phases of the epicardial action potential that should be especially effective in suppressing $\mathbf{J}$ wave activity.

The effectiveness of bepridil in ERS has been reported in a single patient thus far. ${ }^{166}$

No clinical data are available regarding the effectiveness of radiofrequency (RF) ablation in the setting of ERS, despite the fact that low voltage fractionated electrogram activity and high frequency late potentials are observed in the LV in patients with ERS ${ }^{30}$ and in experimental models of ERS (Yoon and Antzelevitch, unpublished observation). Nakagawa et al. ${ }^{30}$ reported the results of a study in which they recorded epicardial electrograms directly from the left ventricle of patients diagnosed with ERS by introducing a multipolar catheter into the left lateral (marginal) coronary vein, anterior interventricular vein (AIV), and middle cardiac vein (MCV) via the coronary sinus. The authors reported late potentials in the bipolar electrograms recorded from the left ventricular (LV) epicardium of the ERS patients. ${ }^{30}$

\section{Acknowledgments}

Funding: This study was supported by grant HL47678 from the NHLBI (CA), the Sharpe-Strumia Research Foundation (GXY), and grant NSFC-81370289 from National Natural Science Foundation of China (GXY)

\section{References}

1. Clements SD, Hurst JW. Diagnostic value of ECG abnormalities observed in subjects accidentally exposed to cold. AmJCardiol. 1972; 29:729-734. 
2. Thompson R, Rich J, Chmelik F, Nelson WL. Evolutionary changes in the electrocardiogram of severe progressive hypothermia. JElectrocardiol. 1977; 10:67-70. [PubMed: 833527]

3. Eagle K. Images in clinical medicine. Osborn waves of hypothermia. NEnglJMed. 1994; 10:680.

4. Kraus F. Ueber die wirkung des kalziums auf den kreislauf 1 ). DtschMedWochenschr. 1920; 46:201-203.

5. Sridharan MR, Horan LG. Electrocardiographic J wave of hypercalcemia. AmJCardiol. 1984; 54:672-673.

6. Antzelevitch C, Yan GX. J wave syndromes. Heart Rhythm. 2010; 7:549-558. [PubMed: 20153265]

7. Wasserburger RH, Alt WJ. The normal RS-T segment elevation variant. Am J Cardiol. 1961; 8:184192. [PubMed: 13783301]

8. Mehta MC, Jain AC. Early repolarization on scalar electrocardiogram. Am J MedSci. 1995; 309:305-311.

9. Gussak I, Antzelevitch C. Early repolarization syndrome: clinical characteristics and possible cellular and ionic mechanisms. JElectrocardiol. 2000; 33:299-309. [PubMed: 11099355]

10. Yan GX, Antzelevitch C. Cellular basis for the Brugada syndrome and other mechanisms of arrhythmogenesis associated with ST segment elevation. Circulation. 1999; 100:1660-1666. [PubMed: 10517739]

11. Shu J, Zhu T, Yang L, Cui C, Yan GX. ST-segment elevation in the early repolarization syndrome, idiopathic ventricular fibrillation, and the Brugada syndrome: cellular and clinical linkage. J Electrocardiol. 2005; 38:26-32. [PubMed: 16226071]

12. Haissaguerre M, Derval N, Sacher F, Jesel L, Deisenhofer I, De Roy L, Pasquie JL, Nogami A, Babuty D, Yli-Mayry S, De Chillou C, Scanu P, Mabo P, Matsuo S, Probst V, Le Scouarnec S, Defaye P, Schlaepfer J, Rostock T, Lacroix D, Lamaison D, Lavergne T, Aizawa Y, Englund A, Anselme F, O'Neill M, Hocini M, Lim KT, Knecht S, Veenhuyzen GD, Bordachar P, Chauvin M, Jais P, Coureau G, Chene G, Klein GJ, Clementy J. Sudden cardiac arrest associated with early repolarization. NEnglJ Med. 2008; 358:2016-2023.

13. Nam GB, Kim YH, Antzelevitch C. Augmentation of J waves and electrical storms in patients with early repolarization. NEnglJ Med. 2008; 358:2078-2079.

14. Antzelevitch C. J wave syndromes: molecular and cellular mechanisms. J Electrocardiol. 2013; 46:510-518. [PubMed: 24011992]

15. Mahida S, Derval N, Sacher F, Berte B, Yamashita S, Hooks DA, Denis A, Lim H, Amraoui S, Aljefairi N, Hocini M, Jais P, Haissaguerre M. History and clinical significance of early repolarization syndrome. Heart Rhythm. 2015; 12:242-9. [PubMed: 25257090]

16. Wellens HJ, Schwartz PJ, Lindemans FW, Buxton AE, Goldberger JJ, Hohnloser SH, Huikuri HV, Kaab S, La Rovere MT, Malik M, Myerburg RJ, Simoons ML, Swedberg K, Tijssen J, Voors AA, Wilde AA. Risk stratification for sudden cardiac death: current status and challenges for the futuredagger. EurHeart J. 2014; 35:1642-1651.

17. Macfarlane P, Antzelevitch C, Haissaguerre M, Huikuri HPMRR, Sacher F, Tikkanen J, Wellens H, Yan G-X. CONSENSUS PAPER - EARLY REPOLARIZATION PATTERN. J Amer Coll Cardiol. 2015 In Press.

18. Brugada P, Brugada J. Right bundle branch block, persistent ST segment elevation and sudden cardiac death: a distinct clinical and electrocardiographic syndrome: a multicenter report. JAmCollCardiol. 1992; 20:1391-1396.

19. Kanter RJ, Pfeiffer R, Hu D, Barajas-Martinez H, Carboni MP, Antzelevitch C. Brugada-like syndrome in infancy presenting with rapid ventricular tachycardia and intraventricular conduction delay. Circulation. 2012; 125:14-22. [PubMed: 22090166]

20. Antzelevitch C. Molecular biology and cellular mechanisms of brugada and long QT syndromes in infants and young children. JElectrocardiol. 2001; 34:177-181. [PubMed: 11781953]

21. Wedekind H, Smits JP, Schulze-Bahr E, Arnold R, Veldkamp MW, Bajanowski T, Borggrefe M, Brinkmann B, Warnecke I, Funke H, Bhuiyan ZA, Wilde AA, Breithardt G, Haverkamp W. De novo mmutation in the $S C N 5 A$ gene associated with early onset of sudden infant death. Circulation. 2001; 104:1158-1164. [PubMed: 11535573]

22. Antzelevitch C. Brugada syndrome. Pacing ClinElectrophysiol. 2006; 29:1130-1159. 
23. Coronel R, Casini S, Koopmann TT, Wilms-Schopman FJ, Verkerk AO, de Groot JR, Bhuiyan Z, Bezzina CR, Veldkamp MW, Linnenbank AC, van der Wal AC, Tan HL, Brugada P, Wilde AA, de Bakker JM. Right ventricular fibrosis and conduction delay in a patient with clinical signs of Brugada syndrome: a combined electrophysiological, genetic, histopathologic, and computational study. Circulation. 2005; 112:2769-2777. [PubMed: 16267250]

24. Bastiaenen R, Hedley PL, Christiansen M, Behr ER. Therapeutic hypothermia and ventricular fibrillation storm in early repolarization syndrome. Heart Rhythm. 2010; 7:832-834. [PubMed: 20206297]

25. Federman NJ, Mechulan A, Klein GJ, Krahn AD. Ventricular fibrillation induced by spontaneous hypothermia in a patient with early repolarization syndrome. J Cardiovasc Electrophysiol. 2013; 24:586-588. [PubMed: 23140469]

26. Nam GB. Idiopathic ventricular fibrillation, early repolarization and other J wave-related ventricular fibrillation syndromes. Circ J. 2012; 76:2723-2731. [PubMed: 23131759]

27. Yan GX, Antzelevitch C. Cellular basis for the electrocardiographic J wave. Circulation. 1996; 93:372-379. [PubMed: 8548912]

28. McIntyre WF, Perez-Riera AR, Femenia F, Baranchuk A. Coexisting early repolarization pattern and Brugada syndrome: recognition of potentially overlapping entities. J Electrocardiol. 2012; 45:195-198. [PubMed: 22178622]

29. Kawata H, Noda T, Yamada Y, Okamura H, Satomi K, Aiba T, Takaki H, Aihara N, Isobe M, Kamakura S, Shimizu W. Effect of sodium-channel blockade on early repolarization in inferior/ lateral leads in patients with idiopathic ventricular fibrillation and Brugada syndrome. Heart Rhythm. 2012; 9:77-83. [PubMed: 21855521]

30. Nakagawa K, Nagase S, Morita H, Ito H. Left ventricular epicardial electrogram recordings in idiopathic ventricular fibrillation with inferior and lateral early repolarization. Heart Rhythm. 2013; 11:314-317. [PubMed: 24184784]

31. McIntyre WF, Perez-Riera AR, Femenia F, Baranchuk A. Coexisting early repolarization pattern and Brugada syndrome: recognition of potentially overlapping entities. J Electrocardiol. 2012; 45:195-8. [PubMed: 22178622]

32. Nam GB, Ko KH, Kim J, Park KM, Rhee KS, Choi KJ, Kim YH, Antzelevitch C. Mode of onset of ventricular fibrillation in patients with early repolarization pattern vs. Brugada syndrome. Eur Heart J. 2010; 31:330-339. [PubMed: 19880418]

33. Benito B, Sarkozy A, Mont L, Henkens S, Berruezo A, Tamborero D, Arzamendi D, Berne P, Brugada R, Brugada P, Brugada J. Gender differences in clinical manifestations of Brugada syndrome. J Am Coll Cardiol. 2008; 52:1567-1573. [PubMed: 19007594]

34. Kamakura T, Kawata H, Nakajima I, Yamada Y, Miyamoto K, Okamura H, Noda T, Satomi K, Aiba T, Takaki H, Aihara N, Kamakura S, Kimura T, Shimizu W. Significance of non-type 1 anterior early repolarization in patients with inferolateral early repolarization syndrome. J Am Coll Cardiol. 2013; 62:1610-1618. [PubMed: 23850930]

35. Matsumoto AM. Fundamental aspects of hypogonadism in the aging male. Reviews in urology. 2003; 5(Suppl 1):S3-s10. [PubMed: 16985941]

36. Kalla H, Yan GX, Marinchak R. Ventricular fibrillation in a patient with prominent J (Osborn) waves and ST segment elevation in the inferior electrocardiographic leads: a Brugada syndrome variant? J Cardiovasc Electrophysiol. 2000; 11:95-98. [PubMed: 10695469]

37. Aizawa Y, Sato A, Watanabe H, Chinushi M, Furushima H, Horie M, Kaneko Y, Imaizumi T, Okubo K, Watanabe I, Shinozaki T, Aizawa Y, Fukuda K, Joo K, Haissaguerre M. Dynamicity of the J-wave in idiopathic ventricular fibrillation with a special reference to pause-dependent augmentation of the J-wave. J Am Coll Cardiol. 2012; 59:1948-1953. [PubMed: 22624834]

38. Nademanee K. Sudden unexplained death syndrome in southeast Asia. American Journal of Cardiology. 1997; 79(6A):10-11. [PubMed: 9080856]

39. Patel RB, Ng J, Reddy V, Chokshi M, Parikh K, Subacius H, sheikh-Ali AA, Nguyen T, Link MS, Goldberger JJ, Ilkhanoff L, Kadish AH. Early repolarization associated with ventricular arrhythmias in patients with chronic coronary artery disease. Circ ArrhythmElectrophysiol. 2010; 3:489-495. 
40. Naruse Y, Tada H, Harimura Y, Hayashi M, Noguchi Y, Sato A, Yoshida K, Sekiguchi Y, Aonuma K. Early repolarization is an independent predictor of occurrences of ventricular fibrillation in the very early phase of acute myocardial infarctions. Circ Arrhythm Electrophysiol. 2012; 5:506-513. [PubMed: 22534250]

41. Furukawa Y, Yamada T, Morita T, Iwasaki Y, Kawasaki M, Kikuchi A, Naito T, Fujimoto T, Ozu K, Kondo T, Sengoku K, Yamamoto H, Masuyama T, Fukunami M. Early repolarization pattern associated with sudden cardiac death: long-term follow-up in patients with chronic heart failure. $\mathrm{J}$ Cardiovasc Electrophysiol. 2013; 24:632-9. [PubMed: 23397903]

42. Gurabi Z, Koncz I, Patocskai B, Nesterenko VV, Antzelevitch C. Cellular mechanism underlying hypothermia-induced VT/VF in the setting of early repolarization and the protective effect of quinidine, cilostazol and milrinone. Circ Arrhythm Electrophysiol. 2014; 7:134-142. [PubMed: 24429494]

43. Antzelevitch C. Genetic, molecular and cellular mechanisms underlying the J wave syndromes. Circ J. 2012; 76:1054-1065. [PubMed: 22498570]

44. Kapplinger JD, Tester DJ, Alders M, et al. An international compendium of mutations in the SCN5A encoded cardiac sodium channel in patients referred for Brugada syndrome genetic testing. Heart Rhythm. 2010; 7:33-46. [PubMed: 20129283]

45. Burashnikov E, Pfeiffer R, Barajas-Martinez H, et al. Mutations in the cardiac L-type calcium channel associated J wave sydnrome and sudden cardiac death. Heart Rhythm. 2010; 7:18721882. [PubMed: 20817017]

46. Cordeiro JM, Marieb M, Pfeiffer R, Calloe K, Burashnikov E, Antzelevitch C. Accelerated inactivation of the L-type calcium due to a mutation in $C A C N B 2 b$ due to a mutation in $C A C N B 2 b$ underlies Brugada syndrome. J MolCell Cardiol. 2009; 46:695-703.

47. Antzelevitch C, Pollevick GD, Cordeiro JM, et al. Loss-of-function mutations in the cardiac calcium channel underline a new clinical entity characterized by ST segment elevation, short QT intervals, and sudden cardiac death. CircRes. 2006; 99:1279.

48. Gurnett CA, De WM, Campbell KP. Dual function of the voltage-dependent Ca2+ channel alpha 2 delta subunit in current stimulation and subunit interaction. Neuron. 1996; 16:431-440. [PubMed: 8789958]

49. Barajas-Martinez H, Hu D, Ferrer T, Onetti CG, Wu Y, Burashnikov E, Boyle M, Surman T, Urrutia J, Veltmann C, Schimpf R, Borggrefe M, Wolpert C, Ibrahim BB, Sanchez-Chapula JA, Winters S, Haissaguerre M, Antzelevitch C. Molecular genetic and functional association of Bugada and early repolarization syndromes with S422L missense mutation in KCNJ8. Heart Rhythm. 2012; 9:548-555. [PubMed: 22056721]

50. Delaney JT, Muhammad R, Blair MA, Kor K, Fish FA, Roden DM, Darbar D. A KCNJ8 mutation associated with early repolarization and atrial fibrillation. Europace. 2012; 14:1428-1432. [PubMed: 22562657]

51. Medeiros-Domingo A, Tan BH, Crotti L, Tester DJ, Eckhardt L, Cuoretti A, Kroboth SL, Song C, Zhou Q, Kopp D, Schwartz PJ, Makielski JC, Ackerman MJ. Gain-of-function mutation S422L in the KCNJ8-encoded cardiac K(ATP) channel Kir6.1 as a pathogenic substrate for J-wave syndromes. Heart Rhythm. 2010; 7:1466-1471. [PubMed: 20558321]

52. Hu D, Barajas-Martinez H, Medeiros-Domingo A, Crotti L, Tester DJ, Veltmann C, Schimpf R, Pfeiffer R, Dezi F, Liu Y, Burashnikov E, Giudicessi JR, Ye D, Wolpert C, Borggrefe M, Schwartz P, Ackerman MJ, Antzelevitch C. Novel mutations in the sodium channel 2 subunit gene (SCN2B) associated with Brugada syndrome and atrial fibrillation. Circulation. 2012; 126:A16521.

53. Riuro H, Beltran-Alvarez P, Tarradas A, Selga E, Campuzano O, Verges M, Pagans S, Iglesias A, Brugada J, Brugada P, Vazquez FM, Perez GJ, Scornik FS, Brugada R. A missense mutation in the sodium channel $B 2$ subunit reveals $S C N 2 B$ as a new candidate gene for Brugada syndrome. Hum Mutat. 2013; 34:961-966. [PubMed: 23559163]

54. Giudicessi JR, Ye D, Tester DJ, Crotti L, Mugione A, Nesterenko VV, Albertson RM, Antzelevitch C, Schwartz PJ, Ackerman MJ. Transient outward current (Ito) gain-of-function mutations in the KCND3-encoded Kv4.3 potassium channel and Brugada syndrome. Heart Rhythm. 2011; 8:1024-1032. [PubMed: 21349352] 
55. Delpón E, Cordeiro JM, Núñez L, Thomsen PEB, Guerchicoff A, Pollevick GD, Wu Y, Kanters JK, Larsen CT, Burashnikov A, Christiansen M, Antzelevitch C. Functional effects of KCNE3 mutation and its role in the development of Brugada syndrome. Circ Arrhythm Electrophysiol. 2008; 1:209-218. [PubMed: 19122847]

56. Olesen MS, Jensen NF, Holst AG, Nielsen JB, Tfelt-Hansen J, Jespersen T, Sajadieh A, Haunso S, Lund JT, Calloe K, Schmitt N, Svendsen JH. A novel nonsense variant in Nav1.5 cofactor MOG1 eliminates its sodium current increasing effect and may increase the risk of arrhythmias. CanJ Cardiol. 2011; 27:523-523. [PubMed: 21621375]

57. Kattygnarath D, Maugenre S, Neyroud N, Balse E, Ichai C, Denjoy I, Dilanian G, Martins RP, Fressart V, Berthet M, Schott JJ, Leenhardt A, Probst V, Le MH, Hainque B, Coulombe A, Hatem SN, Guicheney P. MOG1: a new susceptibility gene for Brugada syndrome. Circ Cardiovasc Genet. 2011; 4:261-268. [PubMed: 21447824]

58. Cerrone M, Lin X, Zhang M, Agullo-Pascual E, Pfenniger A, Chkourko GH, Novelli V, Kim C, Tirasawadischai T, Judge DP, Rothenberg E, Chen HV, Napolitano C, Priori S, Delmar M. Missense mutations in plakophilin-2 cause sodium current deficit and associate with a Brugada syndrome phenotype. Circulation. 2013; 129:1092-1103. [PubMed: 24352520]

59. Hennessey JA, Marcou CA, Wang C, Wei EQ, Wang C, Tester DJ, Torchio M, Dagradi F, Crotti L, Schwartz PJ, Ackerman MJ, Pitt GS. FGF12 is a candidate Brugada syndrome locus. Heart Rhythm. 2013; 10:1886-1894. [PubMed: 24096171]

60. Bezzina CR, Barc J, Mizusawa Y, Remme CA, et al. Common variants at SCN5A-SCN10A and $H E Y 2$ are associated with Brugada syndrome, a rare disease with high risk of sudden cardiac death. Nat Genet. 2013; 45:1044-1049. [PubMed: 23872634]

61. Boukens BJ, Sylva M, de Gier-de VC, Remme CA, Bezzina C, Christoffels VM, Coronel R. Reduced sodium channel function unmasks residual embryonic slow conduction in the adult right ventricular outflow tract. Circ Res. 2013; 113:137-141. [PubMed: 23661717]

62. Hartman ME, Liu Y, Zhu WZ, Chien WM, Weldy CS, Fishman GI, Laflamme MA, Chin MT. Myocardial deletion of transcription factor $\mathrm{CHF} 1 / \mathrm{Hey} 2$ results in altered myocyte action potential and mild conduction system expansion but does not alter conduction system function or promote spontaneous arrhythmias. FASEB J. 2014; 28:3007-3015. [PubMed: 24687990]

63. Ishikawa T, Takahashi N, Ohno S, Sakurada H, Nakamura K, On YK, Park JE, Makiyama T, Horie M, Arimura T, Makita N, Kimura A. Novel $S C N 3 B$ mutation associated with brugada syndrome affects intracellular trafficking and function of Nav1.5. Circ J. 2013; 77:959-967. [PubMed: 23257389]

64. Hu D, Barajas-Martinez H, Burashnikov E, Springer M, Wu Y, Varro A, Pfeiffer R, Koopmann TT, Cordeiro JM, Guerchicoff A, Pollevick GD, Antzelevitch C. A mutation in the beta 3 subunit of the cardiac sodium channel associated with Brugada ECG phenotype. Circ Cardiovasc Genet. 2009; 2:270-278. [PubMed: 20031595]

65. Watanabe H, Koopmann TT, LS S, Yang T, Ingram CR, Schott JJ, Demolombe S, Probst V, Anselme F, Escande D, Wiesfeld AC, Pfeufer A, Kaab S, Wichmann HE, Hasdemir C, Aizawa Y, Wilde AA, Roden DM, Bezzina CR. Sodium channel b1 subunit mutations associated with Brugada syndrome and cardiac conduction disease in humans. J ClinInvest. 2008; 118:2260-2268.

66. Valdivia CR, Ueda K, Ackerman MJ, Makielski JC. GPD1L links redox state to cardiac excitability by PKC-dependent phosphorylation of the sodium channel SCN5A. Am J Physiol Heart Circ Physiol. 2009; 297:H1446-H1452. [PubMed: 19666841]

67. Shy D, Gillet L, Abriel H. Cardiac sodium channel NaV1.5 distribution in myocytes via interacting proteins: the multiple pool model. BiochimBiophys Acta. 2013; 1833:886-894.

68. Weiss R, Barmada MM, Nguyen T, Seibel JS, Cavlovich D, Kornblit CA, Angelilli A, Villanueva F, McNamara DM, London B. Clinical and molecular heterogeneity in the Brugada syndrome: a novel gene locus on chromosome 3. Circulation. 2002; 105:707-713. [PubMed: 11839626]

69. Hu D, Barajas-Martinez H, Medeiros-Domingo A, Crotti L, Veltmann C, Schimpf R, Urrutia J, Alday A, Casis O, Pfeiffer R, Burashnikov E, Caceres G, Tester DJ, Wolpert C, Borggrefe M, Schwartz P, Ackerman MJ, Antzelevitch C. A novel rare variant in $S C N 1 B b$ linked to Brugada syndrome and SIDS by combined modulation of $\mathrm{Na}(\mathrm{v}) 1.5$ and $\mathrm{K}(\mathrm{v}) 4.3$ channel currents. Heart Rhythm. 2012; 9:760-769. [PubMed: 22155597] 
70. Hu D, Barajas-Martinez H, Pfeiffer R, Dezi F, Pfeiffer J, Buch T, Betzenhauser MJ, Belardinelli L, Kahlig KM, Rajamani S, DeAntonio HJ, Myerburg RJ, Ito H, Deshmukh P, Marieb M, Nam GB, Bhatia A, Hasdemir C, Haissaguerre M, Veltmann C, Schimpf R, Borggrefe M, Viskin S, Antzelevitch C. Mutations in SCN1OA are responsible for a large fraction of cases of Brugada syndrome. J Am Coll Cardiol. 2014; 64:66-79. [PubMed: 24998131]

71. Ueda K, Nakamura K, Hayashi T, Inagaki N, Takahashi M, Arimura T, Morita H, Higashiuesato Y, Hirano Y, Yasunami M, Takishita S, Yamashina A, Ohe T, Sunamori M, Hiraoka M, Kimura A. Functional characterization of a trafficking-defective HCN4 mutation, D553N, associated with cardiac arrhythmia. J Biol Chem. 2004; 279:27194-27198. [PubMed: 15123648]

72. Noseworthy PA, Tikkanen JT, Porthan K, Oikarinen L, Pietila A, Harald K, Peloso GM, Merchant FM, Jula A, Vaananen H, Hwang SJ, O'Donnell CJ, Salomaa V, Newton-Cheh C, Huikuri HV. The early repolarization pattern in the general population clinical correlates and heritability. J Am Coll Cardiol. 2011; 57:2284-2289. [PubMed: 21600720]

73. Reinhard W, Kaess BM, Debiec R, Nelson CP, Stark K, Tobin MD, Macfarlane PW, Tomaszewski M, Samani NJ, Hengstenberg C. Heritability of early repolarization: a population-based study. Circ Cardiovasc Genet. 2011; 4:134-138. [PubMed: 21282333]

74. Nunn LM, Bhar-Amato J, Lowe MD, Macfarlane PW, Rogers P, McKenna WJ, Elliott PM, Lambiase PD. Prevalence of J-point elevation in sudden arrhythmic death syndrome families. J Am Coll Cardiol. 2011; 58:286-290. [PubMed: 21737021]

75. Haissaguerre M, Chatel S, Sacher F, Weerasooriya R, Probst V, Loussouarn G, Horlitz M, Liersch R, Schulze-Bahr E, Wilde A, Kaab S, Koster J, Rudy Y, Le MH, Schott JJ. Ventricular fibrillation with prominent early repolarization associated with a rare variant of $\mathrm{KCNJ} 8 / \mathrm{K}_{\mathrm{ATP}}$ channel. J CardiovascElectrophysiol. 2009; 20:93-98.

76. Watanabe H, Nogami A, Ohkubo K, Kawata H, Hayashi Y, Ishikawa T, Makiyama T, Nagao S, Yagihara N, Takehara N, Kawamura Y, Sato A, Okamura K, Hosaka Y, Sato M, Fukae S, Chinushi M, Oda H, Okabe M, Kimura A, Maemura K, Watanabe I, Kamakura S, Horie M, Aizawa Y, Shimizu W, Makita N. Electrocardiographic characteristics and SCN5A mutations in idiopathic ventricular fibrillation associated with early repolarization. Circ ArrhythmElectrophysiol. 2011; 4:874-881.

77. Schwartz PJ, Ackerman MJ, George AL Jr. Wilde AA. Impact of genetics on the clinical management of channelopathies. J Am Coll Cardiol. 2013; 62:169-180. [PubMed: 23684683]

78. Le Scouarnec S, Karakachoff M, Gourraud JB, Lindenbaum P, Bonnaud S, Portero V, DuboscqBidot L, Daumy X, Simonet F, Teusan R, Baron E, Violleau J, Persyn E, Bellanger L, Barc J, Chatel S, Martins R, Mabo P, Sacher F, Haissaguerre M, Kyndt F, Schmitt S, Bezieau S, Le Marec H, Dina C, Schott JJ, Probst V, Redon R. Testing the burden of rare variation in arrhythmiasusceptibility genes provides new insights into molecular diagnosis for Brugada syndrome. Hum Mol Genet. 2015

79. Behr ER, Savio-Galimberti E, Barc J, Holst AG, Petropoulou E, Prins BP, Jabbari J, Torchio M, Berthet M, Mizusawa Y, Yang T, Nannenberg EA, Dagradi F, Weeke P, Bastiaenan R, Ackerman MJ, Haunso S, Leenhardt A, Kaab S, Probst V, Redon R, Sharma S, Wilde A, Tfelt-Hansen J, Schwartz P, Roden DM, Bezzina CR, Olesen M, Darbar D, Guicheney P, Crotti L, Jamshidi Y. Role of common and rare variants in SCN10A: Results from the Brugada syndrome QRS locus gene discovery collaborative study. Cardiovasc Res. 2015

80. Wilde AA, Postema PG, Di Diego JM, Viskin S, Morita H, Fish JM, Antzelevitch C. The pathophysiological mechanism underlying Brugada syndrome: depolarization versus repolarization. J Mol Cell Cardiol. 2010; 49:543-553. [PubMed: 20659475]

81. Morita H, Zipes DP, Wu J. Brugada syndrome: insights of ST elevation, arrhythmogenicity, and risk stratification from experimental observations. Heart Rhythm. 2009; 6:S34-S43. [PubMed: 19880072]

82. Nademanee K, Veerakul G, Chandanamattha P, Chaothawee L, Ariyachaipanich A, Jirasirirojanakorn K, Likittanasombat K, Bhuripanyo K, Ngarmukos T. Prevention of ventricular fibrillation episodes in Brugada syndrome by catheter ablation over the anterior right ventricular outflow tract epicardium. Circulation. 2011; 123:1270-1279. [PubMed: 21403098] 
83. Szel T, Antzelevitch C. Abnormal repolarization as the basis for late potentials and fractionated electrograms recorded from epicardium in experimental models of brugada syndrome. J Am Coll Cardiol. 2014; 63:2037-2045. [PubMed: 24657694]

84. Huikuri HV. Separation of Benign from Malignant J waves. Heart Rhythm. 2015; 12:384-5. [PubMed: 25460858]

85. Aizawa Y, Sato M, Kitazawa H, Aizawa Y, Takatsuki S, Oda E, Okabe M, Fukuda K. Tachycardia-dependent augmentation of "notched J waves" in a general patient population without ventricular fibrillation or cardiac arrest: Not a repolarization but a depolarization abnormality? Heart Rhythm. 2015; 12:376-83. [PubMed: 25460863]

86. Badri M, Patel A, Yan G. Cellular and ionic basis of J-wave syndromes. Trends Cardiovasc Med. 2015; 25:12-21. [PubMed: 25446046]

87. Morita H, Kusano KF, Miura D, Nagase S, Nakamura K, Morita ST, Ohe T, Zipes DP, Wu J. Fragmented QRS as a marker of conduction abnormality and a predictor of prognosis of Brugada syndrome. Circulation. 2008; 118:1697-1704. [PubMed: 18838563]

88. Priori SG, Gasparini M, Napolitano C, Della BP, Ottonelli AG, Sassone B, Giordano U, Pappone C, Mascioli G, Rossetti G, De NR, Colombo M. Risk stratification in Brugada syndrome: results of the PRELUDE (PRogrammed ELectrical stimUlation preDictive valuE) registry. J Am Coll Cardiol. 2012; 59:37-45. [PubMed: 22192666]

89. Terho HK, Tikkanen JT, Junttila JM, Anttonen O, Kentta TV, Aro AL, Kerola T, Rissanen HA, Reunanen A, Huikuri HV. Prevalence and prognostic significance of fragmented QRS complex in middle-aged subjects with and without clinical or electrocardiographic evidence of cardiac disease. Am J Cardiol. 2014; 114:141-7. [PubMed: 24819902]

90. Koncz I, Gurabi Z, Patocskai B, Panama BK, Szel T, Hu D, Barajas-Martinez H, Antzelevitch C. Mechanisms underlying the development of the electrocardiographic and arrhythmic manifestations of early repolarization syndrome. J Mol Cell Cardiol. 2014; 68C:20-28. [PubMed: 24378566]

91. Gurabi Z, Koncz I, Patocskai B, Nesterenko VV, Antzelevitch C. Cellular mechanism underlying hypothermia-induced ventricular tachycardia/ventricular fibrillation in the setting of early repolarization and the protective effect of quinidine, cilostazol, and milrinone. Circ Arrhythm Electrophysiol. 2014; 7:134-42. [PubMed: 24429494]

92. Ghosh S, Cooper DH, Vijayakumar R, Zhang J, Pollak S, Haissaguerre M, Rudy Y. Early repolarization associated with sudden death: insights from noninvasive electrocardiographic imaging. Heart Rhythm. 2010; 7:534-7. [PubMed: 20153422]

93. Viskin S, Adler A, Halkin A, Rosso R. Reply: is the J wave or the ST slope malignant...or neither? J Am Coll Cardiol. 2014; 63:1812-1813. [PubMed: 24315912]

94. Rosso R, Adler A, Halkin A, Viskin S. Risk of sudden death among young individuals with J waves and early repolarization: putting the evidence into perspective. Heart Rhythm. 2011; 8:923929. [PubMed: 21295159]

95. Rosso R, Kogan E, Belhassen B, Rozovski U, Scheinman MM, Zeltser D, Halkin A, Steinvil A, Heller K, Glikson M, Katz A, Viskin S. J-point elevation in survivors of primary ventricular fibrillation and matched control subjects: incidence and clinical significance. J Am Coll Cardiol. 2008; 52:1231-1238. [PubMed: 18926326]

96. Tikkanen JT, Junttila MJ, Anttonen O, Aro AL, Luttinen S, Kerola T, Sager SJ, Rissanen HA, Myerburg RJ, Reunanen A, Huikuri HV. Early repolarization: electrocardiographic phenotypes associated with favorable long-term outcome. Circulation. 2011; 123:2666-2673. [PubMed: 21632493]

97. Rosso R, Glikson E, Belhassen B, Katz A, Halkin A, Steinvil A, Viskin S. Distinguishing "benign” from "malignant early repolarization": The value of the ST-segment morphology. Heart Rhythm. 2012; 9:225-229. [PubMed: 21914497]

98. Rollin A, Maury P, Bongard V, Sacher F, Delay M, Duparc A, Mondoly P, Carrie D, Ferrieres J, Ruidavets JB. Prevalence, prognosis, and identification of the malignant form of early repolarization pattern in a population-based study. Am J Cardiol. 2012; 110:1302-1308. [PubMed: 22819431] 
99. Brugada J, Brugada R, Brugada P. Pharmacological and device approach to therapy of inherited cardiac diseases associated with cardiac arrhythmias and sudden death. JElectrocardiol. 2000; 33(Suppl):41-47. [PubMed: 11265735]

100. Brugada P, Brugada R, Brugada J, Geelen P. Use of the prophylactic implantable cardioverter defibrillator for patients with normal hearts. AmJCardiol. 1999; 83:98D-100D.

101. Priori SG, Wilde AA, Horie M, et al. Executive Summary: HRS/EHRA/APHRS Expert Consensus Statement on the Diagnosis and Management of Patients with Inherited Primary Arrhythmia Syndromes. Heart Rhythm. 2013; 15:1389-1406.

102. van Den Berg MP, Wilde AA, Viersma TJW, Brouwer J, Haaksma J, van der Hout AH, StolteDijkstra I, Bezzina TCR, Van Langen IM, Beaufort-Krol GC, Cornel JH, Crijns HJ. Possible bradycardic mode of death and successful pacemaker treatment in a large family with features of long QT syndrome type 3 and Brugada syndrome. JCardiovascElectrophysiol. 2001; 12:630-636.

103. Bertomeu-Gonzalez V, Ruiz-Granell R, Garcia-Civera R, Morell-Cabedo S, Ferrero A. Syncopal monomorphic ventricular tachycardia with pleomorphism, sensitive to antitachycardia pacing in a patient with Brugada syndrome. Europace. 2006; 8:1048-1050. [PubMed: 17098780]

104. Lee KL, Lau C, Tse H, Wan S, Fan K. Prevention of ventricular fibrillation by pacing in a man with Brugada syndrome. J Cardiovasc Electrophysiol. 2000; 11:935-937. [PubMed: 10969759]

105. Cortez-Dias N, Placido R, Marta L, Bernardes A, Sobral S, Carpinteiro L, de SJ. Epicardial ablation for prevention of ventricular fibrillation in a patient with Brugada syndrome. RevPortCardiol. 2014; 33:305-305.

106. Brugada J, Brugada R, Brugada P. Right bundle-branch block and ST-segment elevation in leads $\mathrm{V}_{1}$ through $\mathrm{V}_{3}$. A marker for sudden death in patients without demonstrable structural heart disease. Circulation. 1998; 97:457-460. [PubMed: 9490240]

107. Chinushi M, Aizawa Y, Ogawa Y, Shiba M, Takahashi K. Discrepant drug action of disopyramide on ECG abnormalities and induction of ventricular arrhythmias in a patient with Brugada syndrome. JElectrocardiol. 1997; 30:133-136. [PubMed: 9141608]

108. Antzelevitch, C.; Brugada, P.; Brugada, J.; Brugada, R.; Nademanee, K.; Towbin, JA. The Brugada syndrome. Futura Publishing Company, Inc.; Armonk, NY: 1999. Clinical approaches to tachyarrhythmias..

109. Minoura Y, Di Diego JM, Barajas-Martinez H, Zygmunt AC, Hu D, Sicouri S, Antzelevitch C. Ionic and cellular mechanisms underlying the development of acquired Brugada syndrome in patients treated with antidepressants. J Cardiovasc Electrophysiol. 2012; 23:423-432. [PubMed: 22034916]

110. Minoura Y, Panama BK, Nesterenko VV, Betzenhauser M, Barajas-Martinez H, Hu D, Di Diego JM, Antzelevitch C. Effect of Wenxin Keli and quinidine to suppress arrhythmogenesis in an experimental model of Brugada syndrome. Heart Rhythm. 2013; 10:1054-1062. [PubMed: 23499631]

111. Johnson P, Lesage A, Floyd WL, Young WG Jr. Sealy WC. Prevention of ventricular fibrillation during profound hypothermia by quinidine. Ann Surg. 1960; 151:490-495. [PubMed: 14407499]

112. Belhassen B, Shapira I, Shoshani D, Paredes A, Miller H, Laniado S. Idiopathic ventricular fibrillation: inducibility and beneficial effects of class I antiarrhythmic agents. Circulation. 1987; 75:809-16. [PubMed: 3829343]

113. Belhassen B, Viskin S, Antzelevitch C. The Brugada syndrome: is an implantable cardioverter defibrillator the only therapeutic option? Pacing Clin Electrophysiol. 2002; 25:1634-1640. [PubMed: 12494624]

114. Alings M, Dekker L, Sadee A, Wilde A. Quinidine induced electrocardiographic normalization in two patients with Brugada syndrome. Pacing ClinElectrophysiol. 2001; 24:1420-1422.

115. Belhassen, B.; Viskin, S. Pharmacologic approach to therapy of Brugada syndrome: quinidine as an alternative to ICD therapy?. In: Antzelevitch, C.; Brugada, P.; Brugada, J.; Brugada, R., editors. The Brugada Syndrome: From Bench to Bedside. Blackwell Futura; Oxford: 2004. p. 202-211.

116. Viskin S, Wilde AA, Tan HL, Antzelevitch C, Shimizu W, Belhassen B. Empiric quinidine therapy for asymptomatic Brugada syndrome: time for a prospective registry. Heart Rhythm. 2009; 6:401-404. [PubMed: 19251219] 
117. Belhassen B, Glick A, Viskin S. Excellent long-term reproducibility of the electrophysiologic efficacy of quinidine in patients with idiopathic ventricular fibrillation and Brugada syndrome. Pacing Clin Electrophysiol. 2009; 32:294-301. [PubMed: 19272057]

118. Marquez MF, Bonny A, Hernandez-Castillo E, De SA, Gomez-Flores J, Nava S, Hidden-Lucet F, Iturralde $\mathrm{P}$, Cardenas M, Tonet J. Long-term efficacy of low doses of quinidine on malignant arrhythmias in Brugada syndrome with an implantable cardioverter-defibrillator: A case series and literature review. Heart Rhythm. 2013; 9:1995-2000. [PubMed: 23059185]

119. Pellegrino PL, Di BM, Brunetti ND. Quinidine for the management of electrical storm in an old patient with Brugada syndrome and syncope. Acta Cardiol. 2013; 68:201-203. [PubMed: 23705565]

120. Probst V, Evain S, Gournay V, Marie A, Schott JJ, Boisseau P, Le MH. Monomorphic ventricular tachycardia due to Brugada syndrome successfully treated by hydroquinidine therapy in a 3-yearold child. J Cardiovasc Electrophysiol. 2006; 17:97-100. [PubMed: 16426410]

121. Schweizer PA, Becker R, Katus HA, Thomas D. Successful acute and long-term management of electrical storm in Brugada syndrome using orciprenaline and quinine/quinidine. Clin Res Cardiol. 2010; 99:467-470. [PubMed: 20221832]

122. Hasegawa K, Ashihara T, Kimura H, Jo H, Itoh H, Yamamoto T, Aizawa Y, Horie M. Long-term pharmacological therapy of Brugada syndrome: is J-wave attenuation a marker of drug efficacy? InternMed. 2014; 53:1523-1526.

123. Marquez MF, Rivera J, Hermosillo AG, Iturralde P, Colin L, Moragrega JL, Cardenas M. Arrhythmic storm responsive to quinidine in a patient with Brugada syndrome and vasovagal syncope. Pacing ClinElectrophysiol. 2005; 28:870-873.

124. Viskin S, Antzelevitch C, Marquez MF, Belhassen B. Quinidine: a valuable medication joins the list of 'endangered species'. Europace. 2007; 12:1105-1106. [PubMed: 17761793]

125. Ohgo T, Okamura H, Noda T, Satomi K, Suyama K, Kurita T, Aihara N, Kamakura S, Ohe T, Shimizu W. Acute and chronic management in patients with Brugada syndrome associated with electrical storm of ventricular fibrillation. Heart Rhythm. 2007; 4:695-700. [PubMed: 17556186]

126. Rosso R, Glick A, Glikson M, Wagshal A, Swissa M, Rosenhek S, Shetboun I, Khalamizer V, Fuchs T, Boulos M, Geist M, Strasberg B, Ilan M, Belhassen B. Outcome after implantation of cardioverter defribrillator in patients with Brugada syndrome: a multicenter Israeli study (ISRABRU). IsrMed AssocJ. 2008; 10:435-439.

127. Belhassen B, Viskin S, Fish R, Glick A, Setbon I, Eldar M. Effects of electrophysiologic-guided therapy with Class IA antiarrhythmic drugs on the long-term outcome of patients with idiopathic ventricular fibrillation with or without the Brugada syndrome. JCardiovasc Electrophysiol. 1999; 10:1301-1312. [PubMed: 10515552]

128. Hermida JS, Denjoy I, Clerc J, Extramiana F, Jarry G, Milliez P, Guicheney P, Di Fusco S, Rey JL, Cauchemez B, Leenhardt A. Hydroquinidine therapy in Brugada syndrome. J Am Coll Cardiol. 2004; 43:1853-1860. [PubMed: 15145111]

129. Mok NS, Chan NY, Chi-Suen CA. Successful use of quinidine in treatment of electrical storm in Brugada syndrome. Pacing ClinElectrophysiol. 2004; 27:821-823.

130. Bouzeman A, Traulle S, Messali A, Extramiana F, Denjoy I, Narayanan K, Marijon E, Hermida JS, Leenhardt A. Long-term follow-up of asymptomatic Brugada patients with inducible ventricular fibrillation under hydroquinidine. Europace. 2014; 16:572-7. [PubMed: 24068450]

131. Antzelevitch C. The Brugada syndrome: ionic basis and arrhythmia mechanisms. JCardiovasc Electrophysiol. 2001; 12:268-272. [PubMed: 11232628]

132. Tsuchiya T, Ashikaga K, Honda T, Arita M. Prevention of ventricular fibrillation by cilostazol, an oral phosphodiesterase inhibitor, in a patient with Brugada syndrome. JCardiovascElectrophysiol. 2002; 13:698-701.

133. Kyriazis K, Bahlmann E, van der SH KH. Electrical storm in Brugada syndrome successfully treated with orciprenaline; effect of low-dose quinidine on the electrocardiogram. Europace. 2009; 11:665-666. [PubMed: 19346290]

134. Maury P, Couderc P, Delay M, Boveda S, Brugada J. Electrical storm in Brugada syndrome successfully treated using isoprenaline. Europace. 2004; 6:130-133. [PubMed: 15018871] 
135. Maury P, Hocini M, Haissaguerre M. Electrical storms in Brugada syndrome: review of pharmacologic and ablative therapeutic options. Indian Pacing Electrophysiol J. 2005; 5:25-34. [PubMed: 16943940]

136. Jongman JK, Jepkes-Bruin N, Ramdat Misier AR, Beukema WP, Delnoy PP, Oude LH, Dambrink JH, Hoorntje JC, Elvan A. Electrical storms in Brugada syndrome successfully treated with isoproterenol infusion and quinidine orally. NethHeart J. 2007; 15:151-155.

137. Watanabe A, Fukushima KK, Morita H, Miura D, Sumida W, Hiramatsu S, Banba K, Nishii N, Nagase S, Nakamura K, Sakuragi S, Ohe T. Low-dose isoproterenol for repetitive ventricular arrhythmia in patients with Brugada syndrome. EurHeart J. 2006; 27:1579-1583.

138. Furniss G. Isoprenaline and quinidine to calm Brugada VF storm. BMJ CaseRep. 2012

139. Shimizu W, Matsuo K, Takagi M, Tanabe Y, Aiba T, Taguchi A, Suyama K, Kurita T, Aihara N, Kamakura S. Body surface distribution and response to drugs of ST segment elevation in Brugada syndrome: clinical implication of eighty-seven-lead body surface potential mapping and its application to twelve-lead electrocardiograms. J Cardiovasc Electrophysiol. 2000; 11:396404. [PubMed: 10809492]

140. Suzuki H, Torigoe K, Numata O, Yazaki S. Infant case with a malignant form of Brugada syndrome. J Cardiovasc Electrophysiol. 2000; 11:1277-1280. [PubMed: 11083249]

141. Tanaka H, Kinoshita O, Uchikawa S, Kasai H, Nakamura M, Izawa A, Yokoseki O, Kitabayashi H, Takahashi W, Yazaki Y, Watanabe N, Imamura H, Kubo K. Successful prevention of recurrent ventricular fibrillation by intravenous isoproterenol in a patient with Brugada syndrome. Pacing ClinElectrophysiol. 2001; 24:1293-1294.

142. Miyazaki T, Mitamura H, Miyoshi S, Soejima K, Aizawa Y, Ogawa S. Autonomic and antiarrhythmic drug modulation of ST segment elevation in patients with Brugada syndrome. JAmCollCardiol. 1996; 27:1061-1070.

143. Shimizu W, Kamakura S. Catecholamines in children with congenital long QT syndrome and Brugada syndrome. J Electrocardiol. 2001; 34(Suppl):173-175. [PubMed: 11781952]

144. Sharif-Kazemi MB, Emkanjoo Z, Tavoosi A, Kafi M, Kheirkhah J, Alizadeh A, Sadr-Ameli MA. Electrical storm in Brugada syndrome during pregnancy. Pacing Clin Electrophysiol. 2011; 34:e18-e21. [PubMed: 20353417]

145. Roten L, Derval N, Sacher F, Pascale P, Scherr D, Komatsu Y, Ramoul K, Daly M, Denis A, Shah AJ, Hocini M, Jais P, Haissaguerre M. Heterogeneous response of J wave syndromes to beta-adrenergic stimulation. Heart Rhythm. 2012; 9:1970-1976. [PubMed: 22864265]

146. Kaneko Y, Horie M, Niwano S, Kusano K, Takatsuki S, Kurita T, Mitsuhashi T, Nakajima T, Irie T, Hasegawa K, Noda T, Kamakura S, Aizawa Y, Yasuoka R, Torigoe K, Suzuki H, Ohe T, Shimizu A, Fukuda K, Kurabayashi M, Aizawa Y. Electrical storm in patients with Brugada syndrome is associated with early repolarization. Circ ArrhythmElectrophysiol. 2014

147. Agac MT, Erkan H, Korkmaz L. Conversion of Brugada type I to type III and successful control of recurrent ventricular arrhythmia with cilostazol. ArchCardiovasc Dis. 2013

148. Kanlop N, Chattipakorn S, Chattipakorn N. Effects of cilostazol in the heart. J Cardiovasc Med (Hagerstown). 2011; 12:88-95. [PubMed: 21200326]

149. Bai Y, Muqier, Murakami H, Iwasa M, Sumi S, Yamada Y, Ushikoshi H, Aoyama T, Nishigaki K, Takemura G, Uno B, Minatoguchi S. Cilostazol protects the heart against ischaemia reperfusion injury in a rabbit model of myocardial infarction: focus on adenosine, nitric oxide and mitochondrial ATP-sensitive potassium channels. Clin ExpPharmacolPhysiol. 2011; 38:658665.

150. Shinohara T, Ebata Y, Ayabe R, Fukui A, Okada N, Yufu K, Nakagawa M, Takahashi N. Combination therapy of cilostazol and bepridil suppresses recurrent ventricular fibrillation related to J-wave syndromes. Heart Rhythm. 2014; 11:1441-1445. [PubMed: 24813378]

151. Abud A, Bagattin D, Goyeneche R, Becker C. Failure of cilostazol in the prevention of ventricular fibrillation in a patient with Brugada syndrome. J CardiovascElectrophysiol. 2006; 17:210-212.

152. Szel T, Koncz I, Antzelevitch C. Cellular mechanisms underlying the effects of milrinone and cilostazol to supress arrhythmogenesis associated with Brugada syndrome. Heart Rhythm. 2013; 10:1720-1727. [PubMed: 23911896] 
153. Burashnikov A, Petroski A, Hu D, Barajas-Martinez H, Antzelevitch C. Atrial-selective inhibition of sodium channel current by Wenxin Keli is effective in suppressing atrial fibrillation. Heart Rhythm. 2012; 9:125-131. [PubMed: 21884675]

154. Wang X, Wang X, Gu Y, Wang T, Huang C. Wenxin Keli attenuates ischemia-induced ventricular arrhythmias in rats: Involvement of Ltype calcium and transient outward potassium currents. Mol Med Report. 2013; 7:519-524.

155. Sugao M, Fujiki A, Nishida K, Sakabe M, Tsuneda T, Iwamoto J, Mizumaki K, Inoue H. Repolarization dynamics in patients with idiopathic ventricular fibrillation: pharmacological therapy with bepridil and disopyramide. Journal of Cardiovascular Pharmacology. 2005; 45:545549. [PubMed: 15897781]

156. Murakami M, Nakamura K, Kusano KF, Morita H, Nakagawa K, Tanaka M, Tada T, Toh N, Nishii N, Nagase S, Hata Y, Kohno K, Miura D, Ohe T, Ito H. Efficacy of low-dose bepridil for prevention of ventricular fibrillation in patients with Brugada syndrome with and without SCN5A mutation. J Cardiovasc Pharmacol. 2010; 56:389-395. [PubMed: 20625312]

157. Aizawa Y, Yamakawa H, Takatsuki S, Katsumata Y, Nishiyama T, Kimura T, Nishiyama N, Fukumoto K, Tanimoto Y, Tanimoto K, Mitamura H, Ogawa S, Fukuda K. Efficacy and safety of bepridil for prevention of ICD shocks in patients with Brugada syndrome and idiopathic ventricular fibrillation. IntJ Cardiol. 2013; 168:5083-5085. [PubMed: 23954005]

158. Kang L, Zheng MQ, Morishima M, Wang Y, Kaku T, Ono K. Bepridil up-regulates cardiac Na+ channels as a long-term effect by blunting proteasome signals through inhibition of calmodulin activity. BrJ Pharmacol. 2009; 157:404-414. [PubMed: 19371335]

159. Fish JM, Welchons DR, Kim YS, Lee SH, Ho WK, Antzelevitch C. Dimethyl lithospermate B, an extract of danshen, suppresses arrhythmogenesis associated with the Brugada syndrome. Circulation. 2006; 113:1393-1400. [PubMed: 16534004]

160. Iguchi K, Noda T, Kamakura S, Shimizu W. Beneficial effects of cilostazol in a patient with recurrent ventricular fibrillation associated with early repolarization syndrome. Heart Rhythm. 2013; 10:604-606. [PubMed: 23142636]

161. Kanlop N, Shinlapawittayatorn K, Sungnoon R, Weerateerangkul P, Chattipakorn S, Chattipakorn N. Cilostazol attenuates ventricular arrhythmia induction and improves defibrillation efficacy in swine. CanJ Physiol Pharmacol. 2010; 88:422-428. [PubMed: 20555410]

162. Endoh M, Yanagisawa T, Taira N, Blinks JR. Effects of new inotropic agents on cyclic nucleotide metabolism and calcium transients in canine ventricular muscle. Circulation. 1986; 73:III117III133. [PubMed: 2417745]

163. Rapundalo ST, Grupp I, Grupp G, Abdul MM, Solaro RJ, Schwartz A. Myocardial actions of milrinone: characterization of its mechanism of action. Circulation. 1986; 73:III134-III144. [PubMed: 2417746]

164. Atarashi H, Endoh Y, Saitoh H, Kishida H, Hayakawa H. Chronotropic effects of cilostazol, a new antithrombotic agent, in patients with bradyarrhythmias. J Cardiovasc Pharmacol. 1998; 31:534-539. [PubMed: 9554801]

165. Matsui K, Kiyosue T, Wang JC, Dohi K, Arita M. Effects of pimobendan on the L-type Ca2+ current and developed tension in guinea-pig ventricular myocytes and papillary muscle: comparison with IBMX, milrinone, and cilostazol. Cardiovasc Drugs Ther. 1999; 13:105-113. [PubMed: 10372225]

166. Aizawa Y, Chinushi M, Hasegawa K, Naiki N, Horie M, Kaneko Y, Kurabayashi M, Ito S, Imaizumi T, Aizawa Y, Takatsuki S, Joo K, Sato M, Ebe K, Hosaka Y, Haissaguerre M, Fukuda $\mathrm{K}$. Electrical storm in idiopathic ventricular fibrillation is associated with early repolarization. J Am Coll Cardiol. 2013; 62:1015-1019. [PubMed: 23747791]

167. Antzelevitch C, Yan GX, Viskin S. Rationale for the use of the terms J-wave syndromes and early repolarization. J Am Coll Cardiol. 2011; 57:1587-1590. [PubMed: 21474038]

168. Patocskai B, Antzelevitch C. Expert Opinion on Orphan Drugs. Expert opinion on orphan drugs. 2015

169. Yan GX, Antzelevitch C. Cellular basis for the electrocardiographic J wave. Circulation. 1996; 93:372-9. [PubMed: 8548912] 
170. Priori SG, Napolitano C, Gasparini M, Pappone C, Della BP, Giordano U, Bloise R, Giustetto C, De Nardis R, Grillo M, Ronchetti E, Faggiano G, Nastoli J. Natural history of Brugada syndrome: insights for risk stratification and management. Circulation. 2002; 105:1342-1347. [PubMed: 11901046]

171. Probst V, Veltmann C, Eckardt L, Meregalli PG, Gaita F, Tan HL, Babuty D, Sacher F, Giustetto C, Schulze-Bahr E, Borggrefe M, Haissaguerre M, Mabo P, Le Marec H, Wolpert C, Wilde AAM. Long-term prognosis of aatients diagnosed with Brugada syndrome: results from the FINGER Brugada Syndrome Registry. Circulation. 2010; 121:635-643. [PubMed: 20100972]

172. Delise P, Allocca G, Marras E, Giustetto C, Gaita F, Sciarra L, Calo L, Proclemer A, Marziali M, Rebellato L, Berton G, Coro L, Sitta N. Risk stratification in individuals with the Brugada type 1 ECG pattern without previous cardiac arrest: usefulness of a combined clinical and electrophysiologic approach. EurHeart J. 2011; 32:169-176.

173. Antzelevitch C, Brugada P, Borggrefe M, Brugada J, Brugada R, Corrado D, Gussak I, LeMarec H, Nademanee K, Perez Riera AR, Shimizu W, Schulze-Bahr E, Tan H, Wilde A. Brugada syndrome: report of the second consensus conference. Heart Rhythm. 2005; 2:429-440. [PubMed: 15898165]

174. Takagi M, Aonuma K, Sekiguchi Y, Yokoyama Y, Aihara N, Hiraoka M. The prognostic value of early repolarization ( $\mathrm{J}$ wave) and ST-segment morphology after $\mathrm{J}$ wave in Brugada syndrome: Multicenter study in Japan. Heart Rhythm. 2013; 10:533-539. [PubMed: 23274366]

175. Kawata H, Morita H, Yamada Y, Noda T, Satomi K, Aiba T, Isobe M, Nagase S, Nakamura K, Fukushima KK, Ito H, Kamakura S, Shimizu W. Prognostic significance of early repolarization in inferolateral leads in Brugada patients with documented ventricular fibrillation: a novel risk factor for Brugada syndrome with ventricular fibrillation. Heart Rhythm. 2013; 10:1161-1168. [PubMed: 23587501]

176. Adler A, Rosso R, Viskin D, Halkin A, Viskin S. What do we know about the "malignant form" of early repolarization? J Am Coll Cardiol. 2013; 62:863-869. [PubMed: 23770177]

177. Watanabe H, Makiyama T, Koyama T, Kannankeril PJ, Seto S, Okamura K, Oda H, Itoh H, Okada M, Tanabe N, Yagihara N, Kamakura S, Horie M, Aizawa Y, Shimizu W. High prevalence of early repolarization in short QT syndrome. Heart Rhythm. 2010; 7:647-652. [PubMed: 20206319]

178. Gang ES, Priori SS, Chen PS. Short Coupled Premature Ventricular Contraction Initiating Ventricular Fibrillation in a Patient with Brugada Syndrome. J Cardiovasc Electrophysiol. 2004; 15:837-837. [PubMed: 15250875]

179. Viskin S, Rosso R, Rogowski O, Belhassen B. The "short-coupled" variant of right ventricular outflow ventricular tachycardia: a not-so-benign form of benign ventricular tachycardia? J Cardiovasc Electrophysiol. 2005; 16:912-916. [PubMed: 16101636]

180. Qi X, Sun F, An X, Yang J. A case of Brugada syndrome with ST segment elevation through entire precordial leads. ChinJCardiol. 2004; 32:272-273.

181. Ikeda T, Sakurada H, Sakabe K, Sakata T, Takami M, Tezuka N, Nakae T, Noro M, Enjoji Y, Tejima T, Sugi K, Yamaguchi T. Assessment of noninvasive markers in identifying patients at risk in the Brugada syndrome: insight into risk stratification. JAmCollCardiol. 2001; 37:16281634.

182. Yoshioka K, Amino M, Zareba W, Shima M, Matsuzaki A, Fujii T, Kanda S, Deguchi Y, Kobayashi Y, Ikari Y, Kodama I, Tanabe T. Identification of high-risk brugada syndrome patients by combined analysis of late potential and T-wave amplitude variability on ambulatory electrocardiograms. Circ J. 2013; 77:610-618. [PubMed: 23439592]

183. Aizawa Y, Chinushi M, Tagawa M, Furushima H, Okada S, Iijima K, Izumi D, Watanabe H, Komura S. A post-QRS potential in Brugada syndrome: its relation to electrocardiographic pattern and possible genesis. J Am Coll Cardiol. 2008; 51:1720-1721. [PubMed: 18436126]

184. Furushima H, Chinushi M, Okamura K, Iijima K, Komura S, Tanabe Y, Okada S, Izumi D, Aizawa Y. Comparison of conduction delay in the right ventricular outflow tract between Brugada syndrome and right ventricular cardiomyopathy: investigation of signal average ECG in the precordial leads. Europace. 2007; 9:951-956. [PubMed: 17636305]

185. Nagase S, Kusano KF, Morita H, Fujimoto Y, Kakishita M, Nakamura K, Emori T, Matsubara H, Ohe T. Epicardial electrogram of the right ventricular outflow tract in patients with the Brugada 
syndrome: using the epicardial lead. J Am Coll Cardiol. 2002; 39:1992-1995. [PubMed: 12084598]

186. Huang Z, Patel C, Li W, Xie Q, Wu R, Zhang L, Tang R, Wan X, Ma Y, Zhen W, Gao L, Yan GX. Role of signal-averaged electrocardiograms in arrhythmic risk stratification of patients with Brugada syndrome: a prospective study. Heart Rhythm. 2009; 6:1156-1162. [PubMed: 19632627]

187. Merchant FM, Noseworthy PA, Weiner RB, Singh SM, Ruskin JN, Reddy VY. Ability of terminal QRS notching to distinguish benign from malignant electrocardiographic forms of early repolarization. Am J Cardiol. 2009; 104:1402-1406. [PubMed: 19892058]

188. Junttila MJ, Brugada P, Hong K, Lizotte E, de Zutter M, Sarkozy A, Brugada J, Benito B, Perkiomaki JS, Makikallio TH, Huikuri HV, Brugada R. Differences in 12-lead electrocardiogram between symptomatic and asymptomatic Brugada syndrome patients. J CardiovascElectrophysiol. 2008; 19:380-383.

189. Castro Hevia J, Antzelevitch C, Tornés Bárzaga F, Dorantes Sánchez M, Dorticós Balea F, Zayas Molina R, Quiñones Pérez MA, Fayad RY. Tpeak-Tend and Tpeak-Tend dispersion as risk factors for ventricular tachycardia/ventricular fibrillation in patients with the Brugada syndrome. J Am Coll Cardiol. 2006; 47:1828-1834. [PubMed: 16682308]

190. Letsas KP, Weber R, Astheimer K, Kalusche D, Arentz T. Tpeak-Tend interval and TpeakTend/QT ratio as markers of ventricular tachycardia inducibility in subjects with Brugada ECG phenotype. Europace. 2010; 12:271-274. [PubMed: 19897501]

191. Karim Talib A, Sato N, Sakamoto N, Tanabe Y, Takeuchi T, Saijo Y, Kawamura Y, Hasebe N. Enhanced transmural dispersion of repolarization in patients with $\mathbf{J}$ wave syndromes. $\mathbf{J}$ Cardiovasc Electrophysiol. 2012; 23:1109-14. [PubMed: 22612896]

192. Lambiase PD. Tpeak-Tend interval and Tpeak-Tend/QT ratio as markers of ventricular tachycardia inducibility in subjects with Brugada ECG phenotype. Europace. 2010; 12:158-9. [PubMed: 20045864]

193. Uzieblo-Zyczkowska B, Gielerak G, Michalkiewicz D. Usefulness of patient's history and noninvasive electrocardiographic parameters in prediction of ajmaline test results in patients with suspected Brugada syndrome. Archives of medical science : AMS. 2014; 10:899-912. [PubMed: 25395941]

194. Wang JF, Shan QJ, Yang B, Chen ML, Zou JG, Chen C, Xu DJ, Cao KJ. [Tpeak-Tend interval and risk of cardiac events in patients with Brugada syndrome]. Zhonghua xin xue guan bing za zhi. 2007; 35:629-32. [PubMed: 17961428]

195. Talib AK, Sato N, Kawabata N, Sugiyama E, Sakamoto N, Tanabe Y, Fujino T, Takeuchi T, Saijo Y, Akasaka K, Kawamura Y, Hasebe N. Repolarization characteristics in early repolarization and brugada syndromes: insight into an overlapping mechanism of lethal arrhythmias. J Cardiovasc Electrophysiol. 2014; 25:1376-84. [PubMed: 25329037]

196. Makimoto H, Nakagawa E, Takaki H, Yamada Y, Okamura H, Noda T, Satomi K, Suyama K, Aihara N, Kurita T, Kamakura S, Shimizu W. Augmented ST-segment elevation during recovery from exercise predicts cardiac events in patients with Brugada syndrome. J Am Coll Cardiol. 2010; 56:1576-1584. [PubMed: 21029874]

197. Tatsumi H, Takagi M, Nakagawa E, Yamashita H, Yoshiyama M. Risk stratification in patients with Brugada syndrome: analysis of daily fluctuations in 12-lead electrocardiogram (ECG) and signal-averaged electrocardiogram (SAECG). J CardiovascElectrophysiol. 2006; 17:705-711.

198. Haissaguerre M, Extramiana F, Hocini M, Cauchemez B, Jais P, Cabrera JA, Farre G, Leenhardt A, Sanders P, Scavee C, Hsu LF, Weerasooriya R, Shah DC, Frank R, Maury P, Delay M, Garrigue S, Clementy J. Mapping and ablation of ventricular fibrillation associated with long-QT and Brugada syndromes. Circulation. 2003; 108:925-928. [PubMed: 12925452]

199. Nakagawa E, Takagi M, Tatsumi H, Yoshiyama M. Successful radiofrequency catheter ablation for electrical storm of ventricular fibrillation in a patient with Brugada syndrome. Circ J. 2008; 72:1025-1029. [PubMed: 18503235]

200. Shah AJ, Hocini M, Lamaison D, Sacher F, Derval N, Haissaguerre M. Regional substrate ablation abolishes Brugada syndrome. J Cardiovasc Electrophysiol. 2011; 22:1290-1291. [PubMed: 21457386] 
201. Sunsaneewitayakul B, Yao Y, Thamaree S, Zhang S. Endocardial mapping and catheter ablation for ventricular fibrillation prevention in Brugada syndrome. J Cardiovasc Electrophysiol. 2012; 23(Suppl 1):S10-S16. [PubMed: 22988965]

202. Shimizu W, Antzelevitch C, Suyama K, Kurita T, Taguchi A, Aihara N, Takaki H, Sunagawa K, Kamakura S. Effect of sodium channel blockers on ST segment, QRS duration, and corrected QT interval in patients with Brugada syndrome. JCardiovasc Electrophysiol. 2000; 11:1320-1329. [PubMed: 11196553]

203. Matana A, Goldner V, Stanic K, Mavric Z, Zaputovic L, Matana Z. Unmasking effect of propafenone on the concealed form of the Brugada phenomenon. Pacing ClinElectrophysiol. 2000; 23:416-418.

204. Brugada R, Brugada J, Antzelevitch C, Kirsch GE, Potenza D, Towbin JA, Brugada P. Sodium channel blockers identify risk for sudden death in patients with ST-segment elevation and right bundle branch block but structurally normal hearts. Circulation. 2000; 101:510-515. [PubMed: 10662748]

205. Fish JM, Extramiana F, Antzelevitch C. Tedisamil abolishes the arrhythmogenic substrate responsible for VT/VF in an experimental model of the Brugada syndrome. Heart Rhythm. 2004; 1(1S):S158.

206. Fish JM, Extramiana F, Antzelevitch C. AVE0118, an $\mathrm{I}_{\text {to }}$ and $\mathrm{I}_{\mathrm{Kur}}$ blocker, suppresses VT/VF in an experimental model of the Brugada syndrome. Circulation. 2004; 110(17):III-193. 


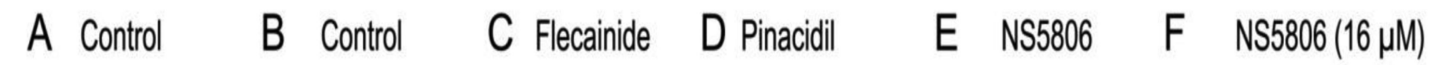
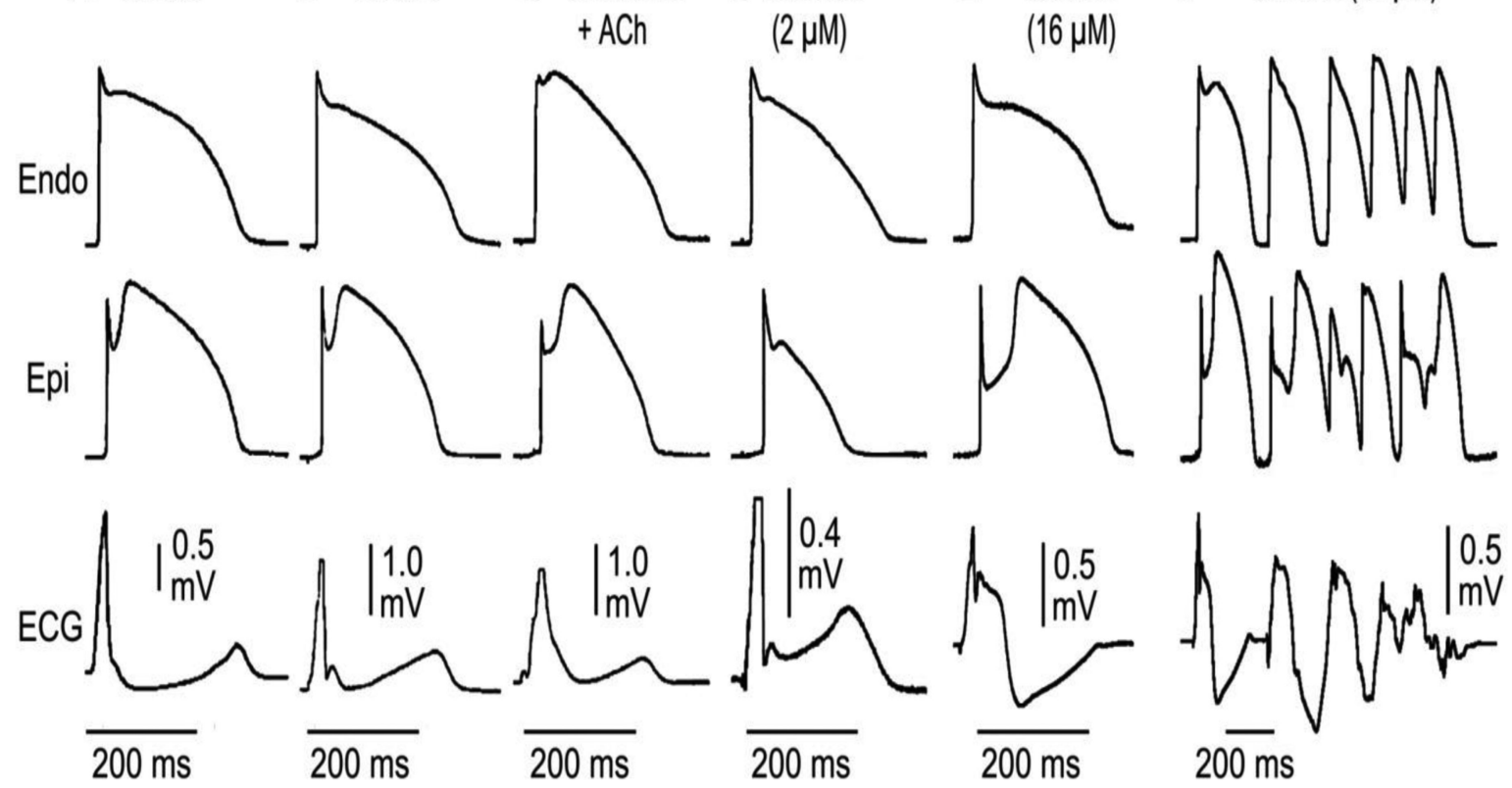

Figure 1.

Mechanisms underlying the different manifestations of the early repolarization pattern in the ECG. Each panel shows transmembrane action potentials simultaneously recorded from the epicardial and endocardial regions of an arterially-perfused canine left ventricular wedge preparation together with a transmural ECG. Under the conditions indicated, the transmural voltage gradients created by the appearance of an action potential notch in epicardium but not endocardium gives rise to an elevated $\mathrm{J}$ wave onset, $\mathrm{J}_{\mathrm{O}}$, (A), as distinct $\mathrm{J}$ wave (B), slurring to the terminal part of the QRS (C), a distinct J wave together with a ST elevation (D), a gigantic J wave appearing as an ST segment elevation (E). It is under these conditions that we see the development of polymorphic VT (F).Modified from ${ }^{167}$, with permission. 


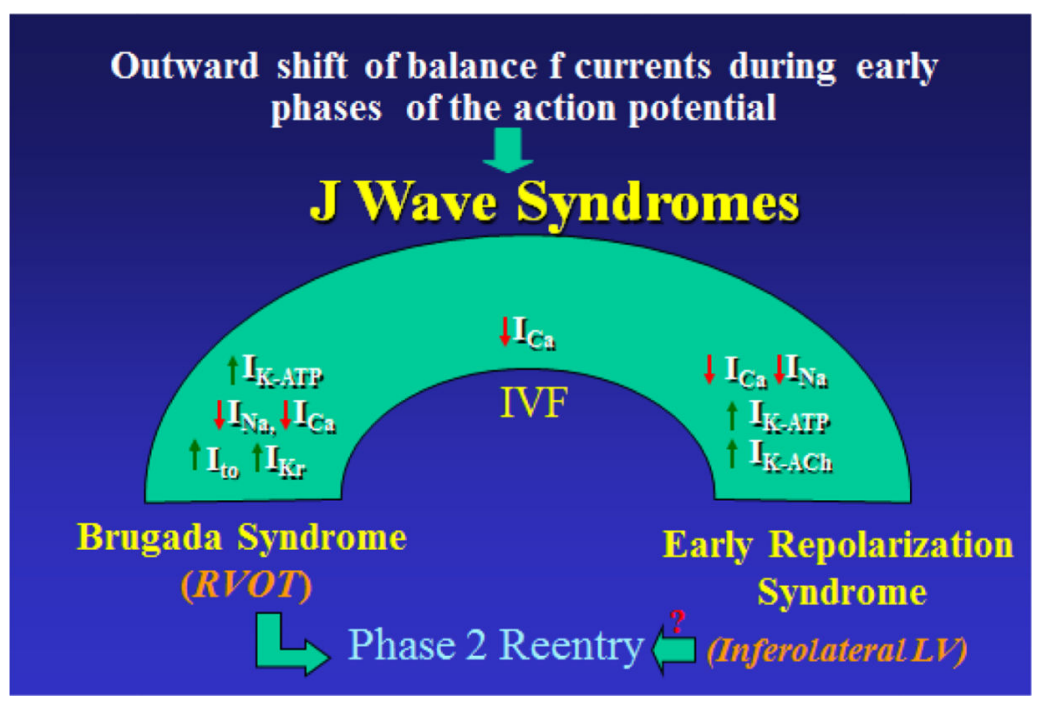

Figure 2.

$\mathrm{J}$ wave Syndromes. Schematic depicts our working hypothesis that an outward shift in repolarizing current due to a decrease in sodium or calcium channel currents or an increase in $\mathrm{I}_{\mathrm{to}}, \mathrm{I}_{\mathrm{K}-\mathrm{ATP}}, \mathrm{I}_{\mathrm{Kr}}$ or $\mathrm{I}_{\mathrm{K}-\mathrm{ACh}}$, or other outward currents can give rise to accentuated $\mathrm{J}$ waves associated with the BrS, Early Repolarization Syndrome and some forms of IVF. The particular phenotype depends on what part of the heart is principally affected and which ion channels are involved. Accentuation of thee $\mathrm{J}$ waves in the right ventricular outflow tract (RVOT) gives rise to BrS, whereas accentuation in the infero-lateral left ventricle (LV) gives rise to ERS. 


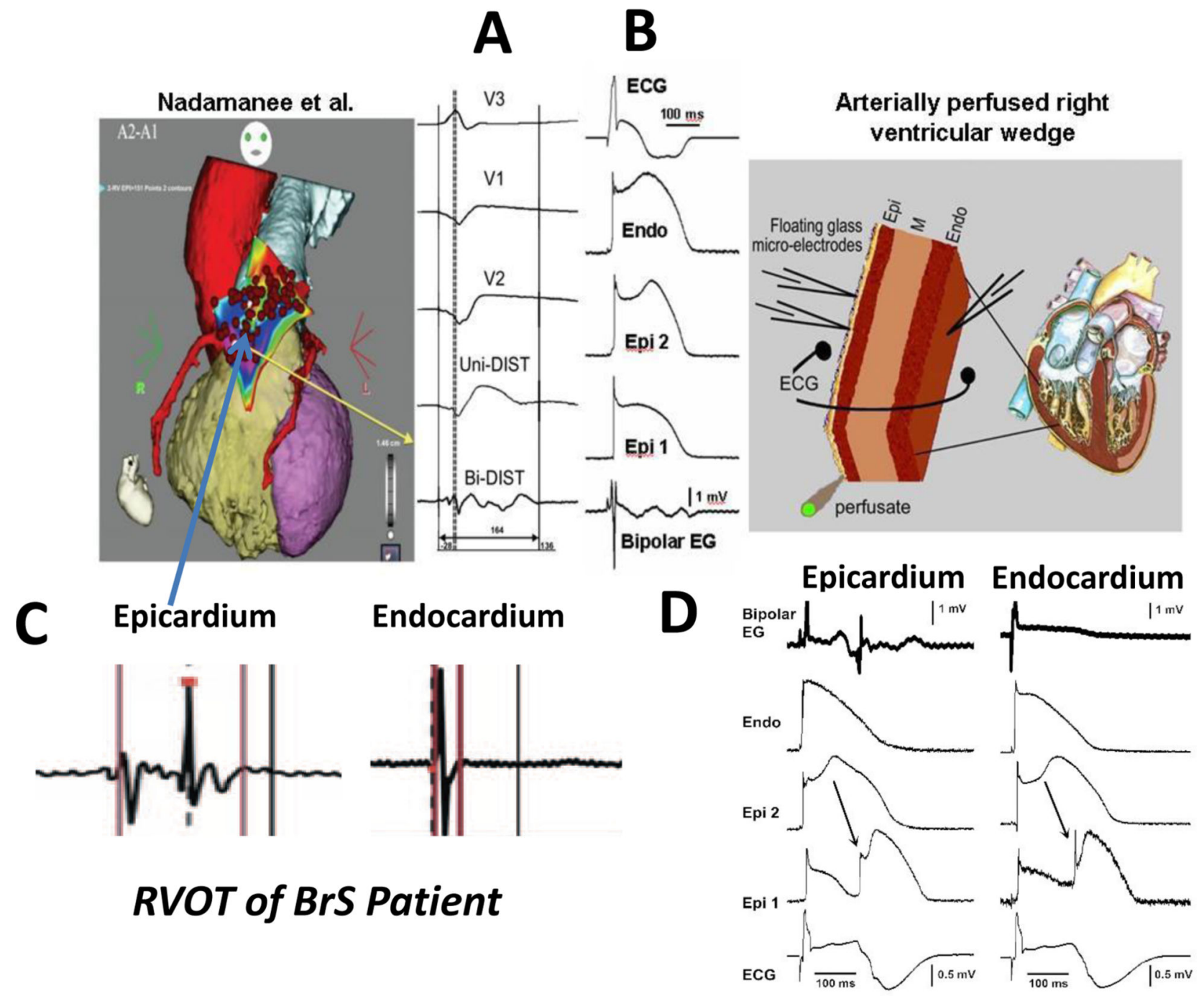

Figure 3.

Heterogeneities in the appearance of the epicardial action potential second upstroke gives rise to fractionated epicardial electrogram (EG) activity and concealed phase 2 reentry gives rise to high frequency late potentials in the setting of Brugada syndrome (BrS). A: Shown are right precordial lead recordings, unipolar and bipolar EGs from the right ventricular outflow tract of a BrS patient. B: ECG, action potentials from endocardium (Endo) and two epicardial (Epi) sites, and a bipolar epicardial EG (Bipolar EG) all simultaneously recorded from a coronary-perfused right ventricular wedge preparation treated with the $\mathrm{I}_{\text {to }}$ agonist NS5806 $(5 \mu \mathrm{M})$ and the calcium channel blocker verapamil $(2 \mu \mathrm{M})$ to induce the Brugada phenotype. Basic cycle length=1000 ms. C: Bipolar EGs recorded from the epicardial and endocardial surfaces of the RVOT in a patient with BrS. The epicardial EG displays fractionated electrogram activity as well as a high frequency late potential late potential (130 msec delay). D: Bipolar electrograms recorded from the epicardium and endocardium of a coronary-perfused wedge model of BrS, together with AP recordings from an endocardial and two epicardial sites and a transmural ECG. The clinical data are modified from 
Nademanee et al. ${ }^{82}$ and the experimental data are from Szel and co-workers ${ }^{83}$, with permission). 


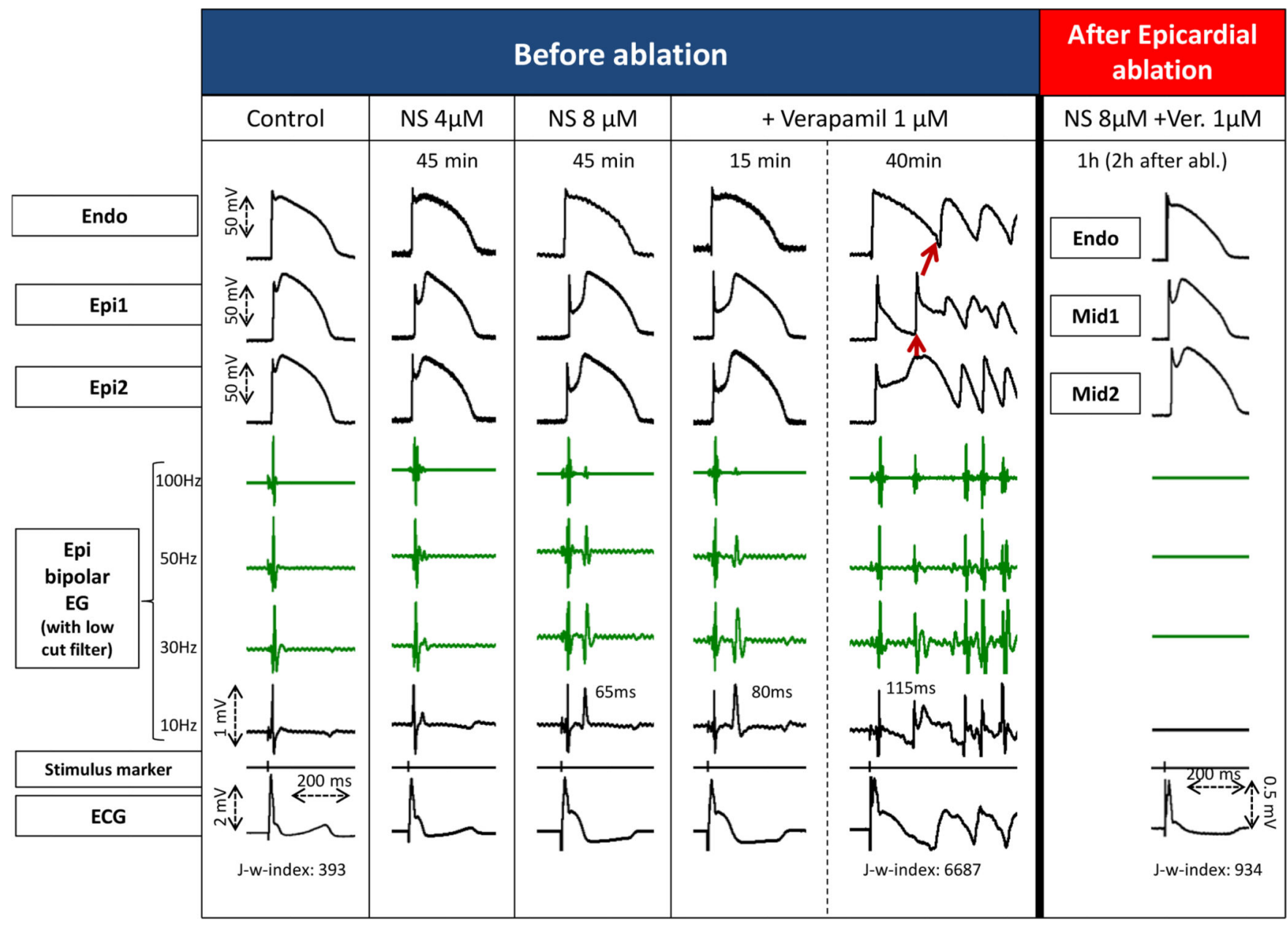

Figure 4.

Radiofrequency ablation of the epicardial surface abolishes the BrS ECG and suppresses arrhythmogenesis in coronary-perfused canine right ventricular wedge model of $\mathrm{BrS}$. Transmembrane action potentials (AP) were simultaneously recorded from one endocardial (Endo) and two epicardial (Epi) sites together with epicardial bipolar electrograms (EG) and a transmural pseudo-ECG. The epicardial bipolar EGs were recorded at $10-1000 \mathrm{~Hz}$ bandwidth (black trace), and were simultaneously band-pass filtered at $30-200 \mathrm{~Hz}, 50-200 \mathrm{~Hz}$ and 100-200Hz (green traces). Column 1: Control. Column 2: Recorded 45 min after the addition of the $\mathrm{I}_{\text {to }}$-agonist NS5806 $(4 \mu \mathrm{M})$ to the coronary perfusate. Column 3: Recorded 45 min after the concentration of NS5806 was raised to $8 \mu \mathrm{M}$. High and low frequency late potentials (LP) are apparent in the EG recordings resulting from progressive delay in the appearance of the second upstroke of the Epi AP secondary to accentuation of the AP notch. Column 4: Recorded $15 \mathrm{~min}$ after the addition of the $\mathrm{I}_{\mathrm{Ca}}$-blocker verapamil $(1 \mu \mathrm{M})$ to the coronary perfusate. Column 5: Recorded after $40 \mathrm{~min}$ of exposure to verapamil $(1 \mu \mathrm{M})$. Loss of the AP dome at Epi1 but not Epi2 gives rise to a phase 2 reentrant beat, which precipitates polymorphic VT. Column 6: Recorded $2 \mathrm{~h}$ after radiofrequency ablation of the epicardial surface, and $1 \mathrm{~h}$ after reintroduction of the provocative agents to the perfusate (in the same concentration as before ablation). APs are now recorded from the deep subepicardium- 
midmyocardium (Mid1, Mid2) instead of the epicardial surface. Ablation markedly suppressed the BrS phenotype and abolished all arrhythmic activity. Modified from ${ }^{168}$, with permission. 
A

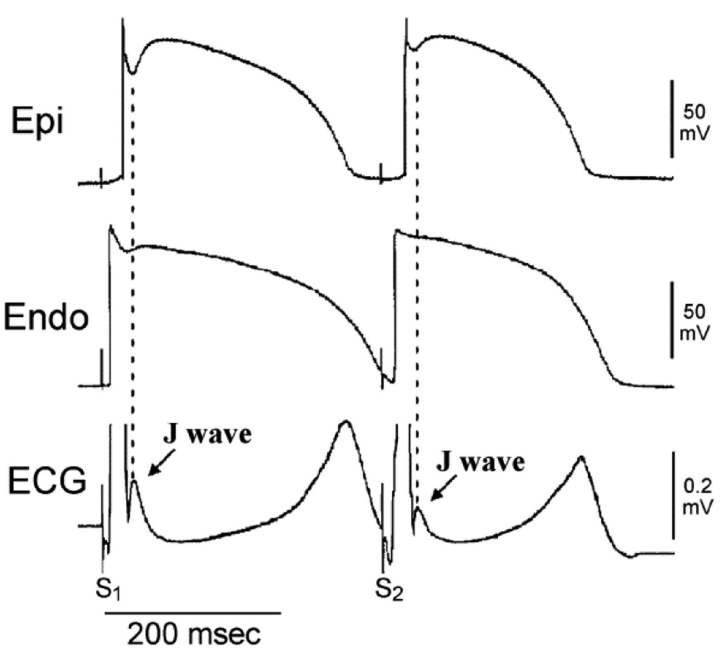

B

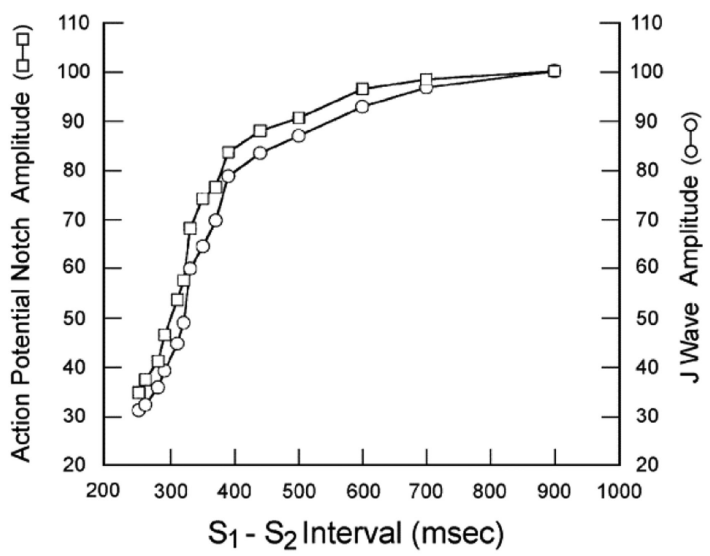

C

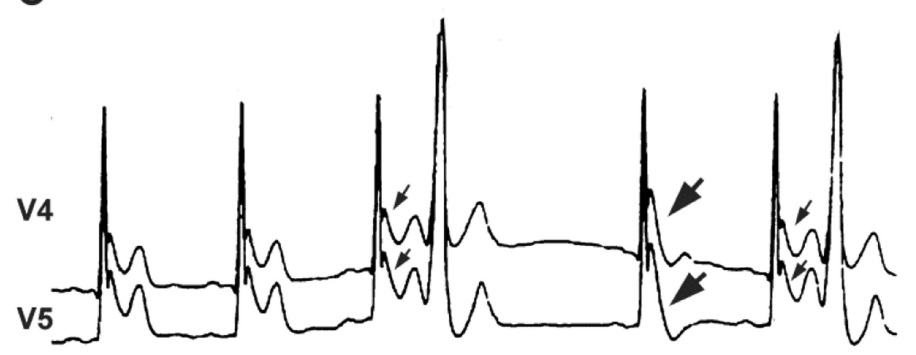

D

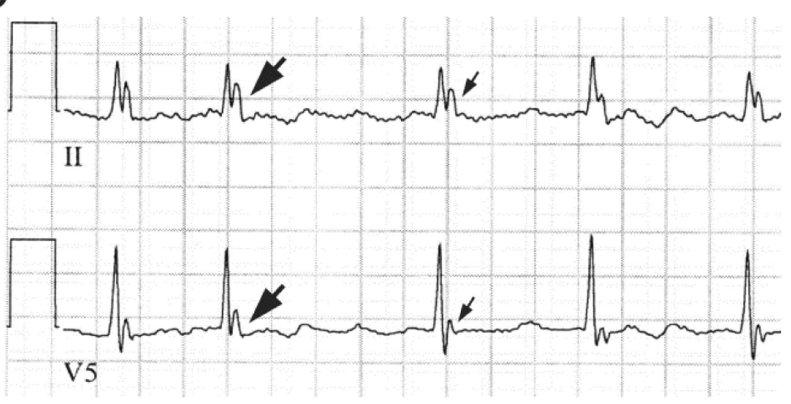

Figure 5.

Rate and pause-dependence of the $\mathrm{J}$ wave in an experimental model and two clinical cases of BrS. A: Transmural ECG and transmembrane action potentials (APs) simultaneously recorded from a canine right ventricular wedge preparation: Prominent $\mathrm{J}$ waves and associated AP notches were observed during basic stimulation (S1-S1=4000ms). Premature stimulation $(\mathrm{S} 1-\mathrm{S} 2=300 \mathrm{~ms}$ ) reduced the epicardial AP notch and $\mathrm{J}$ wave amplitude. B: Plot of epicardial AP notch $(\square)$ and J wave $(\bigcirc)$ amplitude over a range of S1-S2 intervals. Restitution of action potential notch amplitude parallels that of the $\mathrm{J}$ wave. Reproduced from ${ }^{169}$ with permission. C: ECG lead V4-V5 recorded from a 34 year-old Chinese man with idiopathic ventricular fibrillation, showing prominent $\mathrm{J}$ waves that are more accentuated after a pause (thick arrows) compared to those (thin arrows) recorded at shorter R-R intervals. Note that the amplified $\mathrm{J}$ wave after the pause was accompanied by $\mathrm{T}$ wave inversion (V5), an ECG marker associated with a high risk of ventricular fibrillation. D: A Jwave-like deflection at the terminal portion of the QRS in a patient with intra-ventricular conduction delay. In contrast to the $\mathbf{J}$ wave behavior observed in Figure $\mathbf{5 C}$, the end of QRS notch observed in this case is tachycardia-dependent. The terminal deflection is attenuated at longer the R-R interval (thin arrows) and amplified at the shorter R-R interval (thick arrows). Reproduced from ${ }^{86}$, with permission. 


\section{Table 1}

Features Common to Brugada and Early Repolarization Syndromes and Possible Underlying Mechanisms

\begin{tabular}{|c|c|c|c|}
\hline & $\mathrm{BrS}$ & ERS & Possible Mechanism(s) \\
\hline $\begin{array}{l}\text { Region Associated with highest } \\
\text { arrhythmic risk }\end{array}$ & RVOT & Inferior myocardium & Higher levels of $\mathrm{I}_{\mathrm{to}}$ \\
\hline Male Predominance & Yes $(>75 \%)$ & Yes $(>80 \%)$ & $\begin{array}{l}\text { Testosterone modulation of ion currents underlying the } \\
\text { epicardial AP notch }\end{array}$ \\
\hline Average age of first event & $\sim 35-40$ & $\sim 36-42$ & \\
\hline Dynamicity of ECG & High & High & $\begin{array}{l}\text { Autonomic modulation of ion channel currents } \\
\text { underlying early phases of the epicardial AP }\end{array}$ \\
\hline VT/VF trigger & Short-coupled PVC & Short-coupled PVC & Phase 2 reentry \\
\hline Ameliorative response to quinidine & Yes & Yes & Inhibition of $\mathrm{I}_{\mathrm{to}}$ and possible vagolytic effect \\
\hline $\begin{array}{l}\text { Ameliorative response to } \\
\text { Isoproterenol and and milrinone }\end{array}$ & Yes & Yes & Increased $\mathrm{I}_{\mathrm{Ca}}$ and faster heart rate \\
\hline Ameliorative response to cilostazol & Yes & Yes & Increased $\mathrm{I}_{\mathrm{Ca}}$, reduced $\mathrm{I}_{\mathrm{to}}$ and faster heart rate \\
\hline Ameliorative response to pacing & Yes & Yes & $\begin{array}{l}\text { Reduced availability of } \mathrm{I}_{\text {to }} \text { due to slow recovery from } \\
\text { inactivation }\end{array}$ \\
\hline $\begin{array}{l}\text { Vagally-mediated accentuation of } \\
\text { ECG pattern }\end{array}$ & Yes & Yes & $\begin{array}{l}\text { Direct effect to inhibit } \mathrm{I}_{\mathrm{Ca}} \text { and indirect effect to increase } \\
\mathrm{I}_{\text {to }} \text { (due to slowing of heart rate) }\end{array}$ \\
\hline
\end{tabular}

RVOT=right ventricular outflow tract, $\mathrm{AP}=$ action potential; $\mathrm{PVC}=$ premature ventricular contraction 
Table 2

Gene defects associated with the Early Repolarization (ERS) and Brugada (BrS) syndromes.

\begin{tabular}{|l|l|l|l|l|}
\hline \multicolumn{5}{|c|}{ Genetic Defects Associated wih ERS } \\
\hline & Locus & Gene/Protein & Ion Channel & \% of Probands \\
\hline ERS1 & $12 \mathrm{p} 11.23$ & KCNJ8, Kir6.1 & $\uparrow \mathrm{I}_{\mathrm{K}-\mathrm{ATP}}$ & \\
\hline ERS2 & $12 \mathrm{p} 13.3$ & $C A C N A 1 C, C a_{v} 1.2$ & $\downarrow \mathrm{I}_{\mathrm{Ca}}$ & $4.1 \%$ \\
\hline ERS3 & $10 \mathrm{p} 12.33$ & $C A C N B 2 b, C a_{v} \beta 32 b$ & $\downarrow \mathrm{I}_{\mathrm{Ca}}$ & $8.3 \%$ \\
\hline ERS4 & $7 \mathrm{q} 21.11$ & $C A C N A 2 D 1, C a_{v} a ̈ 2 \ddot{a}$ & $\downarrow \mathrm{I}_{\mathrm{Ca}}$ & $4.1 \%$ \\
\hline ERS5 & $12 \mathrm{p} 12.1$ & $A B C C 9, S U R 2 A$ & $\uparrow \mathrm{I}_{\mathrm{K}-\mathrm{ATP}}$ & Rare \\
\hline ERS6 & $3 \mathrm{p} 21$ & $S C N 5 A, N a_{v} 1.5$ & $\downarrow \mathrm{I}_{\mathrm{Na}}$ & Rare \\
\hline ERS7 & $3 \mathrm{p} 22.2$ & $S C N 10 A, N a_{v} 1.8$ & $\downarrow \mathrm{I}_{\mathrm{Na}}$ & \\
\hline
\end{tabular}

\begin{tabular}{|c|c|c|c|c|}
\hline \multicolumn{5}{|c|}{ Genetic Defects Associated with BrS } \\
\hline & Locus & Gene/Protein & Ion Channel & $\%$ of Probands \\
\hline $\mathrm{BrS1}$ & $3 \mathrm{p} 21$ & $S C N 5 A, N a_{v} 1.5$ & $\downarrow \mathrm{I}_{\mathrm{Na}}$ & $11-28 \%$ \\
\hline $\mathrm{BrS2}$ & $3 \mathrm{p} 24$ & GPDIL & $\downarrow \mathrm{I}_{\mathrm{Na}}$ & Rare \\
\hline $\mathrm{BrS} 3$ & $12 \mathrm{p} 13.3$ & CACNA1C, $C a_{v} 1.2$ & $\downarrow \mathrm{I}_{\mathrm{Ca}}$ & $6.6 \%$ \\
\hline BrS4 & $10 \mathrm{p} 12.33$ & $C A C N B 2 b, C a_{v} \beta 2 b$ & $\downarrow \mathrm{I}_{\mathrm{Ca}}$ & $4.8 \%$ \\
\hline BrS5 & $19 \mathrm{q} 13.1$ & $S C N 1 B, N a_{v} \beta 1$ & $\downarrow \mathrm{I}_{\mathrm{Na}}$ & $1.1 \%$ \\
\hline BrS6 & $11 \mathrm{q} 13-14$ & KCNE3, MiRP2 & $\uparrow \mathrm{I}_{\mathrm{to}}$ & Rare \\
\hline $\mathrm{BrS7}$ & $11 \mathrm{q} 23.3$ & $S C N 3 B, N a_{v} \beta 3$ & $\downarrow \mathrm{I}_{\mathrm{Na}}$ & Rare \\
\hline $\mathrm{BrS} 8$ & 12p11.23 & KCNJ8, Kir6.1 & $\uparrow \mathrm{I}_{\mathrm{K} \text {-ATP }}$ & $2 \%$ \\
\hline BrS9 & $7 \mathrm{q} 21.11$ & $C A C N A 2 D 1, C a_{v} a ́ 2 \ddot{a}$ & $\downarrow \mathrm{I}_{\mathrm{Ca}}$ & $1.8 \%$ \\
\hline $\mathrm{BrS} 10$ & $1 \mathrm{p} 13.2$ & $K C N D 3, K_{v} 4.3$ & $\uparrow \mathrm{I}_{\text {to }}$ & Rare \\
\hline BrS11 & $17 \mathrm{p} 13.1$ & $R A N G R F, M O G 1$ & $\downarrow \mathrm{I}_{\mathrm{Na}}$ & Rare \\
\hline $\mathrm{BrS} 12$ & $3 \mathrm{p} 21.2-\mathrm{p} 14.3$ & SLMAP & $\downarrow \mathrm{I}_{\mathrm{Na}}$ & Rare \\
\hline $\mathrm{BrS} 13$ & $12 \mathrm{p} 12.1$ & $A B C C 9, S U R 2 A$ & $\uparrow \mathrm{I}_{\mathrm{K}-\mathrm{ATP}}$ & Rare \\
\hline $\mathrm{BrS} 14$ & $11 \mathrm{q} 23$ & $S C N 2 B, N a_{v} \beta 2$ & $\downarrow \mathrm{I}_{\mathrm{Na}}$ & Rare \\
\hline $\mathrm{BrS} 15$ & $12 \mathrm{p} 11$ & PKP2, Plakophillin-2 & $\downarrow \mathrm{I}_{\mathrm{Na}}$ & Rare \\
\hline $\mathrm{BrS} 16$ & $3 q 28$ & FGF12, FHAF1 & $\downarrow \mathrm{I}_{\mathrm{Na}}$ & Rare \\
\hline $\mathrm{BrS} 17$ & $3 \mathrm{p} 22.2$ & $S C N 10 A, N a_{v} 1.8$ & $\downarrow \mathrm{I}_{\mathrm{Na}}$ & $\sim 16.7 \%$ \\
\hline $\mathrm{BrS} 18$ & $6 q$ & HEY2 (transcriptional factor) & $\uparrow \mathrm{I}_{\mathrm{Na}}$ & Rare \\
\hline $\mathrm{BrS} 19$ & $7 \mathrm{p} 12.1$ & SEMA3A, Semaphorin & $\uparrow \mathrm{I}_{\mathrm{to}}$ & Rare \\
\hline
\end{tabular}




\section{Table 3}

\section{Risk stratifiers of patients with the J wave Syndromes}

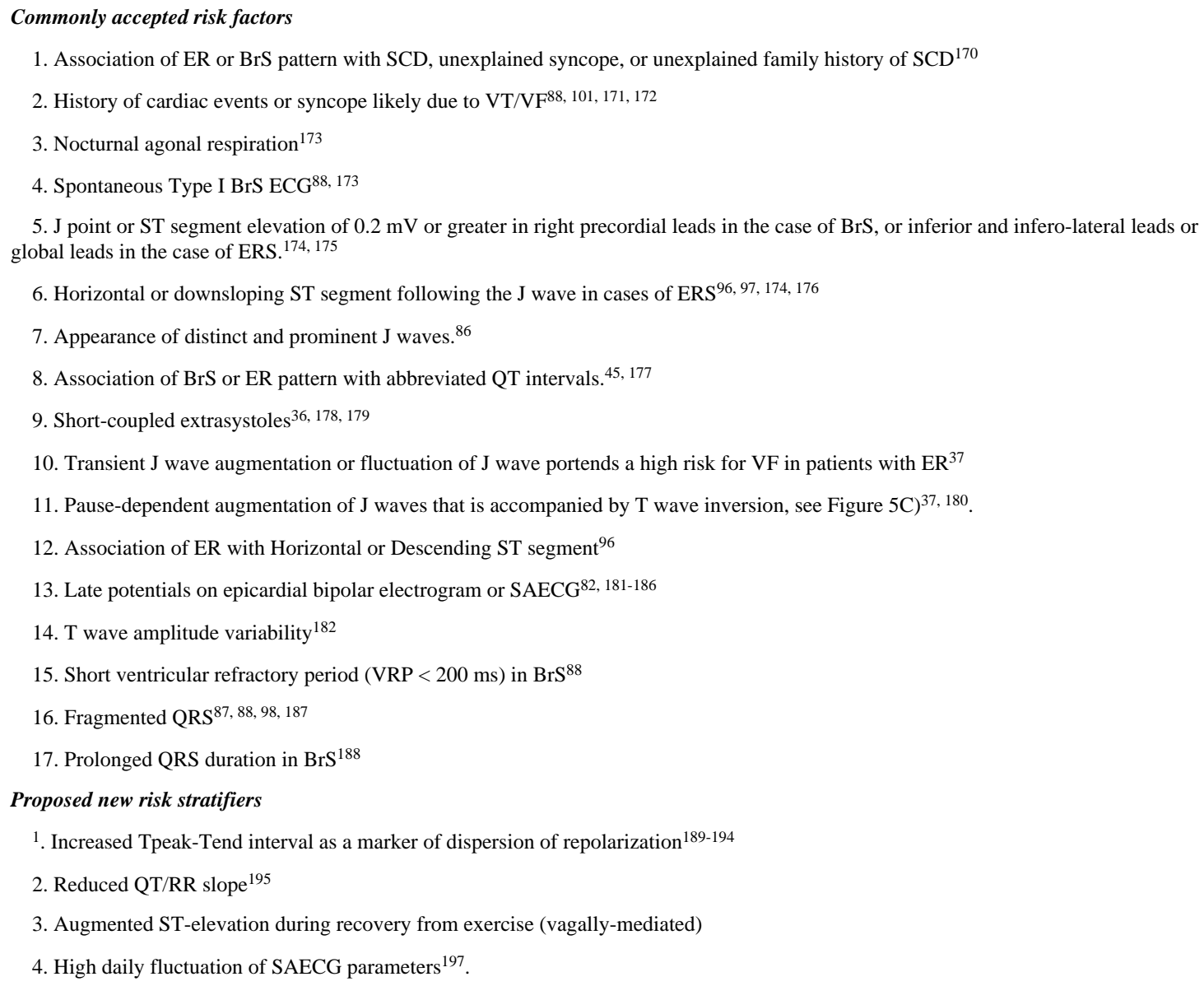




\section{Table 4}

Differential diagnosis of J wave vs. Intra-ventricular conduction defect-mediated notch syndromes. (IVCD)

\begin{tabular}{|c|c|c|}
\hline & J wave & IVCD-induced end QRS notch \\
\hline Male Predominance & Yes & No \\
\hline Average Age at Initial Presentation & Young adults & Relatively sharp appearance \\
\hline Most common Morphology & dome-like smooth appearance & $\begin{array}{c}\text { Tachycardia and prematurity-dependent } \\
\text { augmentation of the notch }\end{array}$ \\
\hline Response to Change in Heart Rate & $\begin{array}{c}\text { Bradycardia- and pause-dependent augmentation } \\
\text { of J wave which may be accompanied by T } \\
\text { wave inversion. }\end{array}$ & $\begin{array}{c}\text { Common History of myocardial infarction and/or } \\
\text { cardiomyopathy }\end{array}$ \\
\hline Structural Heart Diseases & Rare & \multicolumn{2}{c}{} \\
\hline
\end{tabular}


Table 5

Device and Pharmacologic Approach to Therapy of the Brugada Syndrome

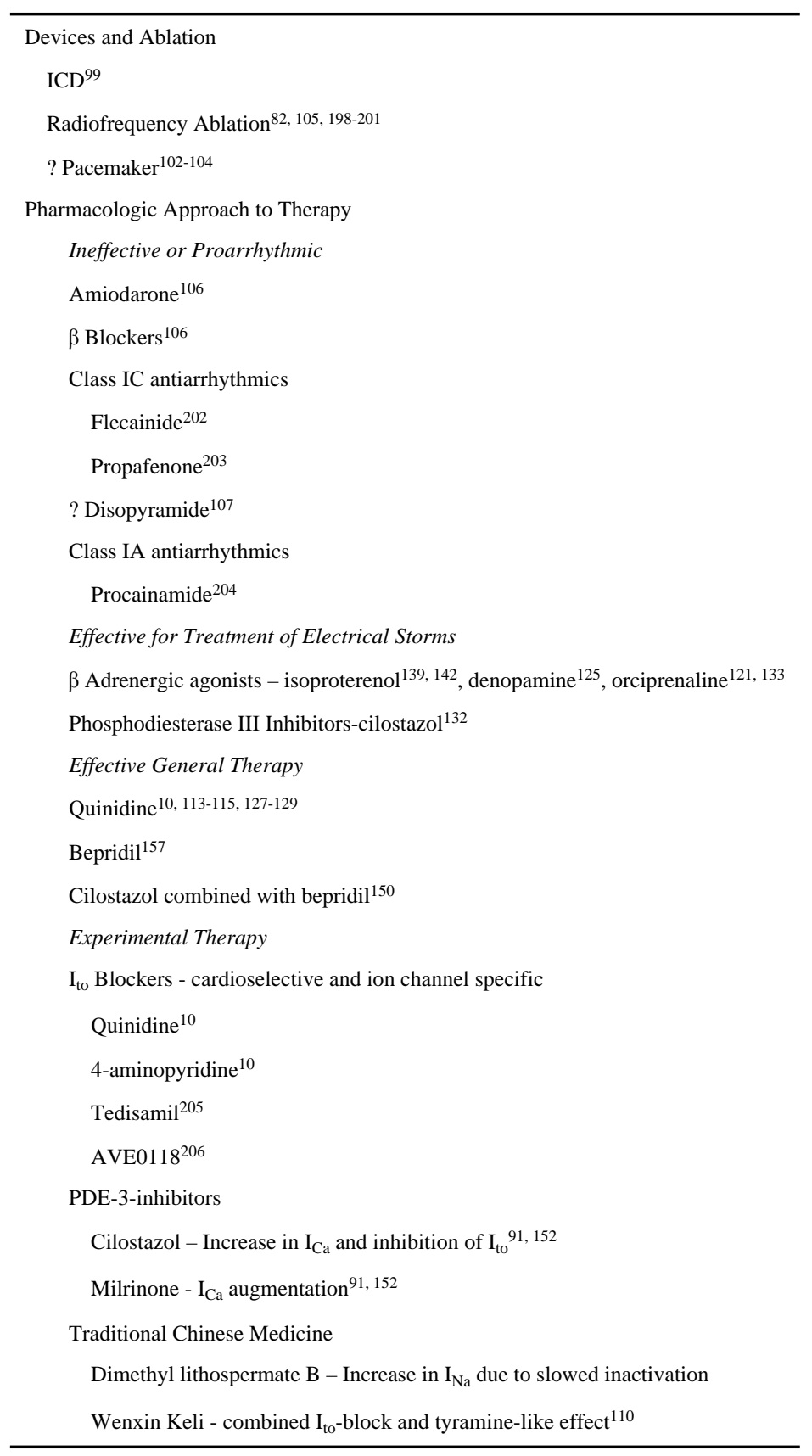

